NBER WORKING PAPER SERIES

GOVERNING MISVALUED FIRMS

Dalida Kadyrzhanova

Matthew Rhodes-Kropf

Working Paper 19799

http://www.nber.org/papers/w19799

\author{
NATIONAL BUREAU OF ECONOMIC RESEARCH \\ 1050 Massachusetts Avenue \\ Cambridge, MA 02138 \\ January 2014
}

\begin{abstract}
We thank Lauren Cohen, Robin Greenwood, Lei Mao, Vinay Nair, Randal Morck, Ramana Nanda, Gordon Phillips, David Robinson, David Scharfstein, Antoinette Schoar, Vish Viswanathan, and Wei Xiong for fruitful discussion and comments, as well as seminar participants at Harvard University, INSEAD, Imperial College, Norwegian School of Economics, Korea Advanced Institute of Science and Technology (KAIST), University of Exeter, and University of Warwick, Hong Kong University of Science and Technology (HKUST), National University of Singapore Business School, The Conference on Empirical Legal Studies (CELS), Research Institute of Industrial Economics (Stockholm, Sweden), University of Bergen, Forth Miami Behavioral Finance Conference. Special thanks to Mozaffar Khan, Leonid Kogan, and George Serafeim for kindly providing us with data on stocks subject to mutual fund buying pressure. All errors are our own. The views expressed herein are those of the authors and do not necessarily reflect the views of the National Bureau of Economic Research.
\end{abstract}

NBER working papers are circulated for discussion and comment purposes. They have not been peerreviewed or been subject to the review by the NBER Board of Directors that accompanies official NBER publications.

(C) 2014 by Dalida Kadyrzhanova and Matthew Rhodes-Kropf. All rights reserved. Short sections of text, not to exceed two paragraphs, may be quoted without explicit permission provided that full credit, including $(\subset$ notice, is given to the source. 
Governing Misvalued Firms

Dalida Kadyrzhanova and Matthew Rhodes-Kropf

NBER Working Paper No. 19799

January 2014

JEL No. G30,G32,G34

\begin{abstract}
Equity overvaluation is thought to create the potential for managerial misbehavior, while monitoring and corporate governance curb misbehavior. We combine these two insights from the literatures on misvaluation and governance to ask 'when does governance matter?' Examining firms with standard long-run measures of corporate governance as they are shocked by plausible misvaluation, we provide consistent evidence that firm performance is impacted by governance when firms become overvalued - overvaluation causes weaker performance in poorly governed firms. Our findings imply that firm oversight is important during market booms, just when stock prices suggest all is well.
\end{abstract}

Dalida Kadyrzhanova

Robert H. Smith School of Business

4422 Van Munching Hall

University of Maryland

College Park, MD 20742

dashik19@gmail.com

Matthew Rhodes-Kropf

Harvard Business School

Rock Center 313

Soldiers Field

Boston, MA 02163

and NBER

mrhodeskropf@hbs.edu 
At least since Keynes (1936) economists have argued that stocks can get irrationally priced and that this divergence from fundamental value may impact managerial decisions. ${ }^{1}$ Overvaluation may help hide misbehavior, create the need to manipulate information, or create the incentive to focus on the short run. Morck, Shleifer and Vishny (1990), Stein (1996), Baker, Stein and Wurgler (2003), Gilchrist, Himmelberg and Huberman (2005), Panageas (2005), Polk and Sapienza (2009), and Campello and Graham (2013), for example, all explore managerial investment decisions in the presence of irrational market prices. Rhodes-Kropf, Robinson and Viswanathan (2005), Shleifer and Vishny (2003) and Rhodes-Kropf and Viswanathan (2004) consider the effect of overvaluation on merger activity. Baker and Wurgler (2002), Welch (2004), and Khan, Kogan and Serafeim (2012) examine the effect of valuation on equity issuance and capital structure. Chernenko, Foley and Greenwood (2012) propose that overvaluation allows firms with greater agency costs to issue equity. Jensen (2005), Bolton, Scheinkman and Xiong (2006) and Bolton, Scheinkman and Xiong (2005) argue that overvaluation is the root cause of much managerial misbehavior. ${ }^{2}$ This body of work suggests that agency costs are procyclical, i.e. higher at the top of the wave.

In a separate literature researchers have theorized and presented evidence that corporate governance can effectively reduce agency costs. In the classic works by Manne (1965) and Scharfstein (1988), insulating managers from shareholders or from the takeover market increases shirking, empire-building, and the extraction of private benefits. More recently Gompers, Ishii and Metrick (2003) create a measure of external governance and document powerful evidence of its impact on firm performance and stock returns. ${ }^{3}$ Following this work many authors report evidence that firms' external governance alters corporate de-

\footnotetext{
${ }^{1}$ See Shleifer (2000), Barberis and Thaler (2003), and Hirshleifer (2001) for summaries of literature on causes and evidence of price deviations from fundamentals.

${ }^{2}$ See Kindleberger (1978) for a discussion of bubbles and fraud.

${ }^{3}$ See also Cremers and Nair (2005), Bebchuk and Cohen (2005), and Bebchuk, Cohen and Ferrell (2009)
} 
cisions and outcomes. For example, measures of better governance have been shown to predict higher return on assets (Core, Guay and Rusticus, 2006), better firing decisions (Huson, Malatesta and Parrino, 2004), better acquisitions (Masulis, Wang and Xie, 2007), more cash reserves (Harford, Mansi and Maxwell, 2008; Yun, 2009), etc.

If overvaluation leads to bad decisions and if strong governance curbs this behavior, then governance should be particularly valuable in times of overvaluation. This simple yet powerful notion has not been previously explored. In this paper we integrate the idea that agency costs are time-varying with the traditional governance view to investigate for the first time if misvaluation causes managerial problems that better governance can counter.

We begin the paper with a simple extension of Holmstrom and Tirole (1997) to fix ideas. In their model all managerial decisions are correct. However in our extension with overvaluation, some managers choose to shirk (or take on a weak projects) in equilibrium. Strong governance reduces the manager's ability to exploit the firm and thus reduces this behavior. Importantly, our extension demonstrates why undervaluation may not have the opposite symmetric effect - with overvaluation the incentive compatibility constraint is violated, while with undervaluation the constraint is simply slack. This implies that the importance of governance should increase with overvaluation but not decrease with undervaluation. ${ }^{4}$

A direct empirical implication of our model is that weakly governed firms should perform poorly only following periods of overvaluation. We take this idea to the data using measures of price deviations from long-run fundamentals (Rhodes-Kropf et al., 2005; Hoberg and Phillips, 2010), as well as an alternative measure of misvaluation based on mutual fund flows (Coval and Stafford, 2007; Khan et al., 2012). ${ }^{5}$

\footnotetext{
${ }^{4}$ This asymmetry does not arise in theories of misvaluation and managerial decisions that are not based on agency problems. For example, Derrien, Kecsks and Thesmar (2012) find that the role of investor heterogeneity in mitigating the effect of misvaluation on managerial decisions is symmetric for over- and undervalued firms.

${ }^{5}$ Measures similar to Rhodes-Kropf et al. (2005) have been used in much recent work (for examples, see Hertzel
} 
In the Compustat/CRSP universe of US publicly traded firms, we estimate deviations of actual market values from those implied by historical pricing. Our main tests focus on the interaction of this misvaluation measure with a measure of corporate governance developed by Gompers et al. (2003) (the GIM-index). We use this governance measure because previous literature (see, for example, Cremers and Ferrell (2012)) has shown that the GIM-index was very stable during the time period we examine (1990-2006), eliminating the concern that firms change their governance in response to overvaluation. ${ }^{6}$ Furthermore, it is important to note that this measure of governance is not correlated with overvaluation. Thus, our empirical approach is to examine future performance of firms with stable governance in response to overvaluation shocks. We also use plausibly exogenous state law changes to provide increased confidence that the effects are caused by governance differences.

We find robust evidence that the positive correlation between governance and future ROA is increasing in measures of overvaluation. In numerous different specification (including firm fixed effects, quantile regressions, eliminating technology firms, alternative valuation measures, etc) we find a strong positive relationship between the interaction of valuation and governance and future ROA.

One interpretation of this finding is that weak governance is particularly detrimental to firms with high values due to unobservables such as growth options. We attempt to distinguish our theory from this alternative in three different ways. First, we test our theoretical prediction that overvalue and undervaluation should not have symmetric effects. Second, we look for effects in portfolio returns since misvaluation implies an ability to find positive alphas. Finally, we reexamine our results using an alternative measure of misvaluation based on mutual fund flows (Coval and Stafford, 2007; Khan et al., 2012). In and Li (2010), Campello and Graham (2013), and Hoberg and Phillips (2010)).

${ }^{6}$ And we can alternatively use the beginning of sample period governance measures. 
all three tests, detailed below, we find support for the idea that governance matters more for overvalued rather than simply highly valued firms.

Our first test is based on our theoretical prediction that overvaluation should cause the bad behavior that governance can counter, but that undervaluation should not have an oppositive symmetric effect. We find that future ROA is positively correlated with corporate governance only after times when misvaluation is also high. Thus, when firms are highly valued, those firms that already had strong governance outperform. On the other hand, during undervalued or typical times we find no difference in performance between firms with different governance measures. These results are consistent with our model's prediction that the role of governance is important during times that the firm is overvalued.

Our second approach is to examine stock market returns since misvaluation implies an ability to find abnormal returns (alphas). ${ }^{7}$ Thus, for weakly governed firms, periods of overvaluation should be followed not only by operating return underperformance, but also by stock market return underperformance. In order to test this prediction, we examine returns from portfolios sorted by our measure of misvaluation in addition to the governance index. Our results show that the significant abnormal returns in the governance hedge portfolio, i.e. the portfolio that is long well-governed "democracy" firms and short poorlygoverned "dictatorship" firms, are concentrated in firms that are overvalued according to our misvaluation measure (a monthly alpha of $119 \mathrm{bp}$ ). By contrast, abnormal returns to the governance hedge portfolio in times of normal or under-valuation are insignificantly different from zero. These results are also consistent with our model where the effects of misvaluation are asymmetric. Importantly, stock market underperformance is hard to

\footnotetext{
${ }^{7}$ In fact, a value-weighted portfolio that shorts firms that are overvalued according to our measure and longs firms that are undervalued, earns a positive monthly alpha of $88 \mathrm{bp}$ (94 bp for an equal-weighted portfolio) in our sample. This suggests we are measuring misvaluation.
} 
explain with an alternative view where our measure of misvaluation captures high valuation rather than overvaluation: if investors valued equity correctly at all times and anticipated differential performance by well-governed firms, governance may be associated with lower ROA, but should not result in differential stock market performance.

One important implication of our results is that abnormal returns to the governance hedge portfolio should be time-varying and systematically related to misvaluation. In an extension to Gompers et al. (2003), Core et al. (2006) demonstrate that the governance hedge portfolio returns are no longer statistically positive when they extend the sample to include the 2000-2004 time period - one hypothesis is that investors learned about the benefits of good governance. When we extend our tests to this time period, we find that among overvalued firms democracy minus dictatorship portfolio returns are still positive and similar to other periods. However, fewer firms become overvalued during this period. These results suggest an alternative explanation for why returns to the governance hedge portfolio have declined after 1999 - this may be due to the limited number of overvalued firms during that period.

In an alternative approach, we re-run our tests using a plausibly exogenous firm-specific measure of overvaluation. Khan et al. (2012) build on Coval and Stafford (2007) and use mutual fund flows to measure stock overvaluation. ${ }^{8}$ They identify $1.5 \%$ of firms that become overvalued when they are subject to substantial buying pressure by mutual funds experiencing large capital inflows. They then show that these stocks experience a cumulative decline in market adjusted returns of $10 \%$ over the next six quarters, as well as a significantly higher probability of a seasoned equity offering, greater insider sales, and higher likelihood of equity M\&A. Our results also hold using this overvaluation measure. In particular, we find that firms that become overvalued according to this measure

\footnotetext{
${ }^{8}$ Khan et al. (2012) argue this measure is "exogenous to the firm since it is associated with who is buying-buyers with excess liquidity-rather than with what is being bought."
} 
subsequently perform relatively better (ROA) if they have better governance, while the performance of firms that are not overvalued is independent of governance. Furthermore, buying the stocks of overvalued firms with good governance and selling the stock of overvalued firms with poor governance produces significant positive alpha, while there is no positive alpha from a long-short portfolio based on governance in the set of firms that are not overvalued. Using this second measure of overvaluation provides significant support for the idea that governance is most important when a firm becomes overvalued.

To address the remaining potential endogeneity concern, that our results are driven by some unobservable firm characteristic correlated with GIM, we follow Bertrand and Mullainathan (2003) and exploit the passage of state business combination laws as a source of exogenous variation in corporate governance. These laws, passed by states at various times between 1984 and 1991, effectively weakened corporate governance in these "treated" firms. This allows us to compare the impact of overvaluation on firms operating in the same state that incorporated in different states and thus have plausibly exogenous differences in corporate governance. Our results provide support for the idea that governance matters most when firms become overvalued.

In the last part of the paper we consider the channel through which governance may affect firm performance in overvalued times. We find that both well- and poorly-governed firms invest more and engage in more acquisition activity in overvalued times, but not differentially so. However, when we examine the future operating efficiency of these firms, we find that labor productivity, cost efficiency, and sales growth are all superior for wellgoverned firms following overvalued times. Thus, there seems to be an effect of governance during overvalued times on investment quality, but not on investment quantity.

Overall, we find consistent evidence that the disciplining effect of governance is strongest during times when firms seem overvalued. The extensive set of different tests we present 
are remarkably consistent with theories related to misvaluation and governance and simultaneously difficult to reconcile with other stories.

One drawback with our work, and all work that relies partly on GIM index, is that it is difficult to know how these governance provisions affect firms. These provisions are often thought to protect firms from the takeover market, allowing for the 'quiet life' and poor performance. Our work would suggest this protection has its largest effect when the firm is overvalued, rather than when the firm is under-performing as one might expect. Potentially this is because the takeover market is most active when firms are highly valued (Rhodes-Kropf et al., 2005), and so being relatively less overvalued is more dangerous for a CEO than being undervalued? Alternatively, firms with more pressure from the takeover market may hire/retain better CEOs (Huson et al., 2004). Potentially, a higher quality CEO is more important during market booms? Our findings raise many interesting questions and potential avenues for future work.

The remainder of the paper is organized as follows. Section I presents an extension of Holmstrom and Tirole (1997) to show the effects of overvaluation. Section II describes the data and our empirical proxies for misvaluation. Section III demonstrates the empirical relationship between governance, misvaluation, and firm performance. Section IV reports how returns depend on the governance misvaluation-relationship. Section V reexamines the main results using mutual fund flows to indicate overvalued firms, while section VI uses state law business combination laws to "treat" firms with different governance. Section VII considers potential mechanisms of action and investigates investment and operational efficiency. Section VIII concludes. 


\section{Misvaluation and Misbehavior}

In this section we present a simple variation on the classic model of Holmstrom and Tirole (1997) to show how overvaluation and undervaluation can have asymmetric effects on 'misbehavior' and furthermore, how better governance can reduce the misbehavior. We do this not to argue that this is the only way in which overvaluation and governance can interact, but rather to provide a framework for looking at the asymmetric effects of misvaluation and governance in the data, as well as to demonstrate that the asymmetric effects we find in the data stem naturally from a small extension to a classic model. All proofs are in appendix A.

\section{A. Standard Setup}

The economy consists of two types of agents: firms and investors. All agents are riskneutral and protected by limited liability.

Each firm has an amount of capital A and one economically viable idea that requires an investment of $I>A>0$ in period 1. Thus, the firm needs $I-A$ in external funds to be able to invest. In period 2 an investment in the project generates a verifiable return equaling either 0 (failure) or $R$ (success). We can think of an economy or industry as containing a continuum of firms with different amounts of capital, A, required investment, $\mathrm{I}$, and potential returns $\mathrm{R}$.

The probability that the project succeeds (and returns $R$ ) is either $p_{H}$ or $p_{L}(\Delta p=$ $\left.p_{H}-p_{L}>0\right)$ depending on the manager's project choice (or equivalently effort choice). Projects are run by managers who receive private benefits of 0 , $\mathrm{b}$ or $\mathrm{B}$ where $0<b<B$. Projects with a private benefit of $\mathrm{b}$ or $\mathrm{B}$ have a low success probability of $p_{L}$ while the 'good', high probability, $p_{H}$, projects have no private benefits. This can be interpreted as reduced effort providing a private benefit of $\mathrm{b}$ or $\mathrm{B}$, and reduced effort in turn reducing the 
probability of success, or as a managerial pet project with higher private benefits but lower expected returns. Thus, without proper incentives managers will choose lower expected return projects with higher private benefits. We will refer to managerial behavior that generates private benefits at the expense of expected return as 'misbehavior'.

As is standard, we assume that investors require a return $\gamma$ and that only the good projects are economically viable, i.e., $p_{H} R-\gamma I>0>p_{L} R-\gamma I+B$. And better governance is assumed to eliminate the highest private benefit project $B$. This is the same as assuming that it reduces the private benefit from $B$ to $b$.

All assumptions above are identical to Holmstrom and Tirole (1997). Now we add the possibility that uninformed investors may misperceive the probability of success or failure.

\section{B. Misvaluation}

We assume managers know $p_{H}$ and $p_{L}$. However, investors are uninformed in that they do not know the true probabilities and instead perceive the probabilities to be $p_{H}^{\prime}=$ $(1+\delta) p_{H}$ and $p_{L}^{\prime}=(1+\delta) p_{L}$ conditional on the actions of the managers, where $\delta>0$ means projects are overvalued and $\delta<0$ means projects are undervalued. ${ }^{9}$

If investors are rational then $p_{H}^{\prime}=p_{H}$ and $p_{L}^{\prime}=p_{L}$ on average (or in expectation). However, whether or not investors are rational, at any given moment in time for any particular firm, sector or market investors may incorrectly judge the probability of success or failure. A difference between the probabilities used by managers and those used by investors could arise fully rationally due to asymmetric information as in Myers and Majluf (1984) (see also Greenwald, Stiglitz and Weiss, 1984). ${ }^{10}$ And of course, any biases, irrationality, or limited cognitive ability could also cause a misperception in the probability of success (see

\footnotetext{
${ }^{9}$ These probabilities are the expected value of the probabilities of the uninformed investors given all available information including the known actions of the participants in the know, or alternatively simply the irrational beliefs of the uninformed investors. An additive formulation $p_{H}^{\prime}=\delta+p_{H}$ produces similar results.

${ }^{10}$ Kumar and Langberg (2009) and Goldman and Slezak (2006) also consider the possibility that informed insiders strategically manipulate outside investors beliefs.
} 
Barberis and Thaler (2003), Hirshleifer (2001), and Shleifer (2000) for summaries). In this paper we take no stand on the source of the mistake only that it is possible for investors to be mistaken.

We assume that uninformed investors still require a return $\gamma$ and have probability beliefs such that only the good projects are economically viable, i.e.

$$
p_{H}^{\prime} R-\gamma I>0>p_{L}^{\prime} R-\gamma I+B
$$

Given the setup, one optimal contract requires the firm to invest $A$, the uninformed investors to invest the balance of $I-A$. The contract then pays everyone nothing if the project fails and if the project succeeds divides the payoff $\mathrm{R}$ into $R_{f}>0$ for the firm and $R_{u}>0$ for the uninformed investor, where $R_{f}+R_{u}=R$.

Given equation (1) uninformed investors will only invest if they believe the manager will choose the good project. Thus,

$$
p_{H}^{\prime} R_{f} \geq p_{L}^{\prime} R_{f}+B
$$

Therefore, the incentive compatible investor belief requires that the firm receive at least

$$
R_{f} \geq B / \Delta p^{\prime}
$$

If this condition holds then uninformed investors will invest $I-A$ if they expect to earn $\gamma$ on this investment. Thus, $p_{H}^{\prime} R_{u} \geq \gamma(I-A)$. This leaves investors with the perception that there is at most $R_{u}=R-B / \Delta p^{\prime}$ to compensate investors, so the maximum perceived pledgable expected income is $p_{H}^{\prime}\left[R-B / \Delta p^{\prime}\right]$. Therefore, we can conclude that only firms 
with enough assets, A, such that

$$
A>\bar{A}(\gamma)=I-\frac{p_{H}^{\prime}}{\gamma}\left[R-B / \Delta p^{\prime}\right]
$$

can finance their project, i.e. firms must have this minimum amount of cash in order to attract outside finance.

Given the required uninformed investor returns of $\gamma$ on their investment of $I-A$, the firm's payoff if the project is successful is

$$
R_{f}=R-\gamma(I-A) / p_{H}^{\prime}
$$

Given this, the manager will only choose the good project if

$$
\text { Manager } I C \quad R_{f}=R-\gamma(I-A) / p_{H}^{\prime} \geq B / \Delta p
$$

Note that the Manager IC and the investors' beliefs about the manager IC, equation (3) are different. As the following proposition shows, this will lead to equilibrium manager misbehavior that comes as a surprise to investors.

PROPOSITION 1: When investors overvalue firms $(\delta>0)$, firms with

$$
B / \Delta p>R-\gamma(I-A) / p_{H}^{\prime} \geq B / \Delta p^{\prime}
$$

will receive investment and managers will choose the worse project in equilibrium. When investors correctly value or undervalue firms $(\delta \leq 0)$ then all managers will choose the good project.

The investors invest expecting the manager to choose the good project. However, be- 
cause investors have over estimated the probability of success they do not realize that the manager is better off shirking and getting larger private benefits. Furthermore as the following corollary shows, the more overvaluation there is the more misbehavior will occur.

COROLLARY 1: When investors overvalue firms $(\delta>0)$, increased overvaluation ( $\delta$ increases) will cause more firms to receive investment and find their manager choose the poor project. When investors correctly or undervalue firms $(\delta \leq 0)$, decreased undervaluation ( $\delta$ decreases) will cause fewer firms to receive investment but no change in managerial decisions.

Thus, the proposition and corollary tell us that overvaluation leads to misbehavior and more overvaluation leads to more misbehavior. At the same time undervaluation lowers investment but no misbehavior occurs when firms are undervalued because the conditions of proposition (1) cannot be met. ${ }^{11}$

Even if investors know that misvaluation and misbehavior are possible, as long as they cannot detect or screen for it ex-ante then they cannot prevent it and must simply raise their return threshold to make up for the fraction with poor projects.

\section{Governance}

When firms can be overvalued corporate governance potentially has an enhanced role compared to the standard Holmstrom and Tirole (1997) setup. In the standard setup no firms choose the bad project in equilibrium. This is because investors will only invest in projects where the firm has enough capital, A, such that the manager can be incented to choose the good project. In the standard set up, corporate governance lowers the amount of capital a firm must have to attract investment but it does not alter equilibrium

\footnotetext{
${ }^{11}$ It is interesting to note that undervaluation ensures that the manager's IC constraint is not binding for any firm. Thus even if investors make small mistakes about other variables, such as underestimate the private benefits, the manager will still choose the good project.
} 
managerial behavior. The following proposition shows that with overvaluation corporate governance actually mitigates the amount of shirking or poor project decisions.

PROPOSITION 2: Better corporate governance reduces the managerial decisions caused by overvaluation that are bad for shareholders. However, better corporate governance does not alter managerial decisions in undervalued firms.

Intuitively, when private benefits are reduced the perceived IC and the true IC are closer, so fewer CEOs choose the worse project in equilibrium. In undervalued firms the true IC is always slack so increased governance has no effect.

When prices do not reflect fundamentals correctly, better governance prevents investments in worse projects. With overvaluation, mechanisms that delegate (incentives/takeover market/etc) do not work as well. Thus, the central idea we wish to demonstrate with this simple model is that overvaluation increases poor managerial investment decisions while governance provisions that enhance discipline on management decrease this behavior. At the same time, undervaluation does not affect managerial decisions. This asymmetry stems naturally from the simple addition of misvaluation to a classic model of governance, and we will see, matches what we find in the data.

\section{Data}

Proposition (2) forms the basis for the key empirical prediction of our model: weak governance should be associated with poor operating performance only following periods of overvaluation. We take this prediction to the data using the measures of misvaluation developed in Rhodes-Kropf et al. (2005) (as extended in Hoberg and Phillips (2010)) and a measure of corporate governance developed by Gompers et al. (2003) (the GIM-index). This section details the construction of these measures and provides details on our main dataset. 
To measure corporate governance, we use the GIM-index which is a simple sum over the 24 governance provisions in described in Gompers et al. (2003). While the GIM-index captures only a certain aspect of corporate governance (the strength of shareholder rights) and is by no means exhaustive, we find it attractive in our setting since it has remained remarkably stable during our sample period (1990-2006). As argued in Gompers et al. (2003) and documented in Cremers and Ferrell (2012), most provisions comprising the index were adopted during the 1980s in response to the hostile takeover wave. By 1990, there was a lot of variation across firms in these provisions. This variation remained in place for the next two decades since firms did not dismantle antitakeover provisions even as the takeover market subsided. In fact, during our sample period, most of the variation in the GIM index is cross-sectional (86.5\%), with only $13.5 \%$ of observations showing a change of at least one in the GIM-index. Most of these changes happened due to institutional investor and/or regulatory pressure. This reduces the concern that firms endogenously alter their governance in response to market valuation conditions, which would be the case with other popular measure of corporate governance such as institutional ownership or managerial compensation. In fact, when we replace the standard GIM-Index with the beginning of period score, we find very similar results.

The data on the GIM-index is drawn from the ISS Riskmetrics governance data set which collects information on a set of 24 governance provisions for about 2,500 unique firms most of which are in the Standard \& Poor's 1500 over the $1990-2006$ period. ${ }^{12}$ We use both the continuous version of the index as well as a dummy variable that indicates whether a firm uses only a few ("Democracy") vs. many ("Dictatorship") governance provisions. Firms are considered Democracy Firms if they have 5 or fewer and Dictatorship if they

\footnotetext{
${ }^{12}$ IRRC volumes are published about every two years $(1990,1993,1995,1998,2000,2002,2004,2006)$. We follow Gompers et al. (2003) in assuming that a provision remains in effect between publication dates. A detailed description of the 24 provisions can be found in Gompers et al. (2003), Appendix A.
} 
have 14 or more governance provisions, respectively. The median firm in our sample has 9 governance provisions.

In order to retrieve information on accounting variables, we match firm-year observations from Riskmetrics to Compustat and retain those with non-missing book value of assets. As is standard in the literature, we exclude dual class firms, financial firms (6000-6999 SIC range), and regulated utilities (4900-4999 SIC range). Finally, we exclude companies with missing data on ROA and explanatory variables. This selection process results in a final set of 15,046 firm-year observations for 2,023 firms from 1990 to 2006 .

Our first measure of relative valuation is based on the measures developed in RhodesKropf et al. (2005) and Hoberg and Phillips (2010). These measures are used in much recent work examining misvaluation. We start with estimating total relative valuation which is a measure of the difference between a firm's actual valuation and one implied by average industry pricing (using historical industry multiples). In particular, following Rhodes-Kropf et al. (2005) and Hoberg and Phillips (2010), for each industry $j$ and year $t$, we first estimate a valuation model from the following industry-level regressions using ten years of lagged data: ${ }^{13}$

$$
\begin{aligned}
\log M_{i j \tau}= & a_{0 j t}+a_{1 j t} \log B_{i j \tau}+a_{2 j t} \log (N I)_{i j \tau}^{+}+a_{3 j t} I_{(<0)} \log (N I)_{i j \tau}^{+} \\
& +a_{4 j t} L E V_{i j \tau}+\varepsilon_{i j \tau} \\
\tau= & t-10, \ldots, t-1
\end{aligned}
$$

where $i$ indexes firms, $j$ indexes industries, and $t$ indexes time. $M_{i j t}$ is the market value of equity, computed by multiplying the common stock price at fiscal year-end (item 199) by common shares outstanding (item 25). $B_{i j t}$ is the book value of equity, constructed as

\footnotetext{
${ }^{13}$ Note that the valuation model is estimated using enitre CRSP/Compustat universe of public firms.
} 
stockholders' equity (Compustat item 216) plus balance sheet deferred taxes and investment tax credit (Compustat item 35) minus the book value of preferred stock (Compustat item 56). NI is net income (Compustat Item 172). Since we estimate the regression in logs, we set negative values of net income to zero and include an indicator function for negative values of net income. $L E V_{i j t}$ is the leverage ratio computed as the ratio of total long-term debt (Compustat item 9) to total assets (item 6). In order to reduce the impact of outliers, all variables are winsorized at the $1 \%$ level.

To obtain a measure of total relative valuation, we use estimated $\alpha_{j t-1}$ 's from our empirical model (8) to predict the following year's valuation for each firm $i$. We then take, for each firm, the difference between its actual valuation in year $t$ and its predicted valuation. This is the estimated total relative valuation (Total RelVal) for each firm in every year. The three-digit SIC industry average of firm total relative valuation (excluding firm $i$ ) is our main measure of overvaluation, referred to as industry relative valuation (Industry RelVal) throughout the paper (see also Hoberg and Phillips (2010) for a similar measure). ${ }^{14}$ As in Hoberg and Phillips (2010), we only rely on historical data in the construction of our relative valuation measure in order to avoid a look-ahead bias.

We also explore robustness of our results to three alternative valuation models. The first alternative model employs a richer valuation model where market-to-book is regressed on a broader set of determinants than in (8) (as in Pastor and Veronesi (2009) and Hoberg and Phillips (2010)). The second alternative model augments the valuation model in (8) with the GIM index. As shown in Gompers et al. (2003), weak corporate governance can result in lower valuation multiples. While there is no evidence to suggest that overvaluation depends on corporate governance, we want to explore this possibility with this robustness

\footnotetext{
${ }^{14}$ We make limited use of the total misvaluation measure because it is correlated with firm-level variables such as firm size. Thus, results using this measure may be driven by spurious correlation between the relative valuation measure and firm characteristics. Industry RelVal, on the other hand, is free from this concern because it is not correlated with firm characteristics.
} 
check. Finally, the third model uses an entirely separate methodology based on mutual fund flows. We describe the fund flow methodology in more detail in Section V. As discussed later, all of our results are robust to these other valuation models.

As in Rhodes-Kropf et al. (2005), we are careful to note that the above regressions capture high relative valuation and not necessarily overvaluation. Almost certainly at least some of the highly valued firms are valued that way for a reason. However, a valueweighted portfolio that is long firms that are undervalued according to our measure and short overvalued firms generates a statistically significant alpha of 88 bp per month (or, 94 bp per month in an equal-weighted portfolio). ${ }^{15}$ This suggests that our measure captures some misvaluation. Furthermore, the Rhodes-Kropf et al. (2005) measure has had such impact because firms with high relative valuation have behaved as would be expected if their prices contained significant overvaluation, and in ways that are otherwise difficult to explain. We will also use an alternative measure of overvaluation based on mutual fund flows - this generates a more limited sample of overvalued firms but our results will continue to hold in this sample. Overall, we will report findings by how they relate to high relative valuation, but we will discuss them in relation to the misvaluation hypothesis, and we will spend a significant part of the paper looking for evidence that our findings are due to overvaluation.

Panel A of Table I presents summary statistics for our sample. Appendix B provides sources and detailed definitions of the control variables, which are standard. Sample moments for corporate governance measures and firm characteristics are in line with previous governance studies that use the Riskmetrics sample (e.g., Gompers et al. (2003)). The industry relative valuation measure is in line with Rhodes-Kropf et al. (2005) and Hoberg

\footnotetext{
${ }^{15}$ Specifically, we form portfolios based on terciles of the distribution of three-month lagged Industry RelVal: overvalued firms are those in the top tercile of this distribution, while undervalued firms are those in the bottom tercile.
} 
and Phillips (2010). In particular, over our sample period, industry relative valuation is on average slightly positive (0.04) with a standard deviation of 0.24 .

Panel B of Table I summarizes pairwise correlations between the industry relative valuation measure and all the other variables. The industry relative valuation is not correlated with our corporate governance measures (the GIM index and indicator variables for Democracy and Dictatorship firms). Moreover, the measure is not significantly correlated with any of our firm-level controls.

Finally, Panel C of Table I summarizes GIM index in subsamples formed by splitting the entire sample into terciles by industry relative valuation. In all terciles, the mean GIM-index is similar and the median GIM-index is identical, suggesting that there is no systematic relation between the GIM index and our measure of relative valuation.

\section{Corporate Governance, Misvaluation, and Firm Performance}

Our model implies that agency costs should be greater in times of overvaluation. We start our empirical investigation by testing whether the relationship between corporate governance and operating performance is stronger for highly valued firms. In particular, if overvaluation leads to a worsening of agency problems and some of the high valuation is measuring overvaluation, then we should see the difference in performance between strongly and weakly governed firms to widen after period of high relative valuation.

\section{A. Main Results}

In order to develop formal multivariate tests of the impact of misvaluation and governance on future operating performance, we use the following baseline model:

$$
R O A_{i j t+k}=b_{j}+b_{t}+b_{1} G I M_{i j t}+b_{2} G I M_{i j t} * M i s V_{i j t}+b_{3} X_{i j t}+e_{i j t}
$$


where $R O A_{i t+k}$ is firm $i$ 's industry (SIC3)-adjusted ROA in $k$ periods ahead of time $t$ with $k=2$ and industry indexed by $j$. The main explanatory variables are the firm's index of antitakeover provisions $\left(G I M_{i j t}\right)$ and its interaction with relative valuation proxy, $M i s V_{i j t}$. $X_{i j t}$ includes the level of relative valuation. In addition, as in Core et al. (2006), we control for firm size, and also include year and industry fixed effects. Finally, to allow for potential correlation of ROA in the same industry, we evaluate statistical significance using robust clustered standard errors adjusted for non-independence of observations within industries (see Wooldridge (2002), p. 275).

The key variable of interest is the coefficient $b_{2}$ on the interaction term. At the margin, the total effect of corporate governance on future operating performance can be calculated by examining the partial derivative of $\mathrm{ROA}_{i t+k}$ with respect to the GIM index: $\frac{\partial R O A_{i j t+k}}{\partial G I M_{i j t}}=b_{1}+b_{2} M i s V_{i j t}$. The null hypothesis is that $b_{2}$ equals zero.

Table II reports our estimates of baseline specification (9). The first column in the table assumes $b_{2}=0$, i.e. it does not allow for the interaction effect of governance with relative valuation. The next two columns examine our main hypothesis that the negative relation between operating performance and governance is magnified during periods of overvaluation. Column (2) shows results from estimating (9) using Industry RelVal - our main measure for misvaluation - as a proxy for $M i s V_{i j t}$. Consistent with our model, the coefficient on the interaction term is negative and statistically significant $(t$-statistic of 2.67). Quantitatively, the magnitude of the interaction effect is large. In particular, the estimated coefficient on the interaction term implies that a one standard deviation increase in industry relative valuation (0.24) makes each provision of the GIM index lower operating performance by about $0.1 \%$. Given that Dictatorship firms have about 10 more provisions compared to Democracy firms, our results imply that the gap in operating performance between weakly and strongly governed firms widens to about $1 \%$ per year following times 
of high relative valuation, which is a sizable effect given the sample average ROA of about $5 \%$.

In Column (3), we report results from re-estimating (9) using total relative valuation as a proxy for $M i s V_{i j t}$. Consistent with our model and confirming results using industry relative valuation measure in Column (2), the negative coefficient on the interaction term is statistically ( $t$-statistic of 2.12) and economically significant: a one standard deviation increase in total relative valuation (0.63) makes each provision of the GIM index lower operating performance by about $0.2 \%$. However, a potential concern with using total relative valuation measure is that it is correlated with some firm characteristics. Thus, the estimated coefficient on the interaction term between the GIM index and total relative valuation could reflect the presence of an interaction effect between corporate governance and some firm characteristic on operating performance as opposed to a greater importance of corporate governance in times of misvaluation. ${ }^{16}$ By contrast, the industry relative valuation measure is computed excluding the firm itself and, as seen from Panel B in Table I, is not correlated with firm-level variables. Thus, in the remainder of the paper, we will only use the industry relative valuation measure as results obtained with this measure are unlikely to be driven by spurious correlation with firm characteristics (although all results also hold using total relative valuation). Essentially we are asking how firms with better or worse governance react to an industry-wide valuation shock as this is part of a firm's overvaluation that is unrelated to firm specific characteristics.

Finally, in Column (4) we restrict the sample to Democracy and Dictatorship firms and use a Dictatorship dummy as a proxy for corporate governance. Core et al. (2006) show that Democracy firms have superior operating performance compared to Dictator-

\footnotetext{
${ }^{16}$ For example, our total relative valuation measure is positively correlated with firm size. If larger firms' operating performance is more sensitive to corporate governance than that of smaller firms, then this could potentially explain our results.
} 
ship firms. We find an economically and statistically significant negative interaction effect between the Dictatorship dummy and our measure of misvaluation, further corroborating our interpretation of the result that weak corporate governance firms significantly underperform firms with strong corporate governance following times when firms are valued above their industry or historical multiples.

The results reported in Table II are obtained using continuous measures of relative valuation. While estimates obtained from interactions with continuous measures have the advantage of using the full available cross-sectional information in relative valuation, they do not tell us from which part of the distribution of relative valuation the result is coming. For example, the negative interaction effect that we find is consistent with both a positive effect of weak governance on ROA in times of relatively low valuation and a negative effect of weak governance on ROA in times of relatively high valuation. Only the latter is consistent with our theory which makes a sharp prediction that there is scope for managerial misbehavior only in times of overvaluation and, thus, poor performance in weakly governed firms should be observed only following periods of overvaluation

Our next set of results examines whether the negative interaction effect in Table II indeed comes from underperformance of weakly governed firms against strongly governed firms only after periods of high relative valuation, as predicted by the theory. In particular, we estimate the effect of the GIM index on ROA within different subsamples based on the empirical distribution of industry relative valuation. We start by defining subsamples based on the upper and lower half (Columns (1)-(2)), the terciles (Columns (3)-(5)), and the quartiles (Columns (6)-(9)) of sample industry relative valuation distribution. Thus, lowest quantiles correspond to subsamples of firms that are valued relatively low ("undervalued"), top quantiles correspond to subsamples of firms that are valued relatively high ("overvalued"), and middle quantiles correspond to subsamples of relatively fairly 
valued firms. We then run our baseline ROA regression (9) separately in each of these subsamples. ${ }^{17}$

The results of the sample-split specification are reported in Table III. There is a negative and statistically significant relation between the GIM index and operating performance at the top of the distribution of industry relative valuation. Importantly, t-tests of the difference of the estimated coefficients of GIM index across industry relative valuation quantiles robustly confirm that, regardless of whether we use splits based on median, terciles, or quartiles, there are always strongly statistically significant differences at the top of the distribution of industry relative valuation, which is precisely where our model tells us there are monitoring benefits from strong governance. Moreover, the negative effect of weak governance in highly (relatively) valued industries is quantitatively significant. For example, the coefficient estimates in Column 5 imply that for firms in the top tercile of industry relative valuation (Panel A), each provision in the GIM index is associated with a 0.2 percentage point lower operating performance. Thus, the gap in operating performance between weakly and strongly governed firms is about $2 \%$ in times of high relative valuation, or double the average effect of weak governance when we don't take overvaluation into account (Column (1) of Table II). Finally, consistent with scope for misbehavior being smaller in periods of under- or fair valuation, the relation between the GIM index and operating performance in bottom and middle quantiles of industry relative valuation is weak, both economically and statistically.

\section{B. Robustness}

Table IV reports results of six sets of robustness checks for our baseline estimates. We estimate the same ROA regression (9) as in Table II, including controls for firm size, and

\footnotetext{
${ }^{17}$ Results for an alternative specification with the GIM index interacted with indicators for each subsample are very similar.
} 
year and industry fixed effects in the estimation. t-statistics based on robust standard errors clustered at the industry level are in parentheses.

We start by showing that our results are robust to changing the baseline specification. First, Column (1) shows that the negative interaction between industry relative valuation measures and the GIM index remains statistically and economically significant when we use median regressions rather than OLS. This robustness check addresses the concern that our results could be driven by outliers in ROA.

Second, we explore the robustness of our results to inclusion of controls for industry concentration and its interaction with the GIM-index. This control is important due to the results in Giroud and Mueller (2011) and Kadyrzhanova and Rhodes-Kropf (2011) who find that the effects of governance provisions depend on the level of industry concentration. If misvaluation is more pronounced in concentrated industries, then our main result could be driven by the substitutability of product market competition and governance mechanisms instead of amplification of agency costs during times of overvaluation. ${ }^{18}$ Following Giroud and Mueller (2011) and Kadyrzhanova and Rhodes-Kropf (2011), we measure industry concentration with the sales-based Herfindahl index of all firms in Compustat in each industry and year. Column (2) shows that our baseline estimates are little changed when we control for industry concentration and its interaction with the GIM index.

Third, in Column (3) we exclude "new economy" firms, as defined in Hand (2003). Here we address the concern that our results could reflect a strongly negative relation between weak corporate governance and operating performance among new economy (high tech) firms rather than for firms with high relative valuation. In fact, Core et al. (2006) argue that the results in Gompers et al. (2003) are partly due to mispricing of these firms in the late 1990s. While the economic significance of the interaction term drops slightly $(-0.003$

\footnotetext{
${ }^{18}$ It should be noted that this interpretation of our results is inconsistent with the evidence in Hoberg and Phillips (2010) that overvaluation occurs primarily in competitive, not concentrated, industries.
} 
instead of -0.004 in Table II), it remains economically and statistically significant.

Fourth, we verify robustness of our results to one additional specification. In Column (4) we estimate the baseline ROA regression (9) with firm fixed effects instead of industry fixed effects. This specification allows us to control for time-invariant determinants of ROA. We find that the interaction between the GIM-index and our measure of relative valuation remains reliably negative.

The last two columns show that our results are robust to using two alternative measures of relative valuation. First, Column (5) shows that our results is robust to using a more elaborate valuation model where market-to-book is regressed on firm size, firm age, a dividend dummy, firm leverage, ROE, and volatility of profitability (as in Pastor and Veronesi (2009) and Hoberg and Phillips (2010)). Second, Column (6) shows that our baseline results are virtually unchanged when we augment the basic valuation model (8) with the GIM index. This robustness check addresses the concern that, as shown in Gompers et al. (2003), weak corporate governance is related to valuation multiples. Overall, these results show that our main results are not driven by any particular choice of a valuation model nor by the failure to include relevant determinants into the valuation model.

Overall, our results in this section offer evidence of a significant time-variation in the agency costs of weak corporate governance. We find that firms with weak corporate governance significantly underperform firms with strong corporate governance but only following times when their industries are valued above their historical multiples. These results are consistent with our theory that strong corporate governance is especially important during periods of overvaluation when agency costs are high and managers make poor decisions. However, if our valuation measure has only captured highly but correctly valued firms, then alternatively our findings suggest the need for a new theory of governance that accounts for the asymmetry - governance matters in high value times but not 
in low value times. ${ }^{19}$

\section{Corporate Governance, Misvaluation, and Equity Returns}

We have shown evidence that weak governance is correlated with worse future operating performance following periods of high relative valuation and not during periods of fair or low relative valuation. These results are consistent with our theory that governance counters the effects of overvaluation and has little effect on undervalued firms. If the time-variation in agency costs we document is indeed driven by overvaluation and this overvaluation is (by definition) unanticipated by the market, then we expect that periods of overvaluation will be followed not only by operating return underperformance, but also by stock market return underperformance of weakly governed firms relative to wellgoverned firms.

In order to test this hypothesis, we examine returns to trading strategies that are jointly based on measures of corporate governance and our measures of relative valuation. In particular, in Table $\mathrm{V}$, we examine returns to portfolios sorted by our measure of relative valuation in addition to governance proxies. As is standard in the literature, we compute abnormal returns to such trading strategies using a four-factor calendar-time portfolio method. The abnormal return is the intercept $\alpha$ of the following regression:

$$
R_{t}=\alpha+\beta_{1} \times R M R F_{t}+\beta_{2} \times S M B_{t}+\beta_{3} \times H M L_{t}+\beta_{4} \times U M D_{t}+\varepsilon_{t},
$$

where $R_{t}$ is the excess return on a given portfolio in month $t, R M R F_{t}$ is the return on the market portfolio minus the risk-free rate, $S M B_{t}$ is the size factor, $H M L_{t}$ is the book-to-

\footnotetext{
${ }^{19}$ The asymmetry in our findings implies that poorly governed firms mean revert (in ROA terms) faster than well governed firms after high value times but don't mean revert faster after low value times. This is predicted by the theory of misvaluation and governance, and shows that it is not the case the poorly governed firms simply have a faster mean reverting ROA process.
} 
market factor, and $U M D_{t}$ is the momentum factor. All factors are from Kenneth French's web site.

Gompers et al. (2003) show that a portfolio that is long in strong governance (Democracy) firms and short in weak governance (Dictatorship) firms has generated a significant abnormal return in the period between September 1990 and December 1999. To facilitate comparison with these results, in Columns (1)-(4) we limit our analysis to the same time period. We sort all sample firms first on governance (Democracy and Dictatorship) and then on relative valuation (terciles of industry relative valuation measures), which gives us a total of $2 \times 3=6$ portfolios: one Democracy portfolio and one Dictatorship portfolio for each tercile of industry relative valuation. For each industry relative valuation tercile, we then construct a value- and equal-weighted hedge portfolio, analogous to Gompers et al. (2003), that is long in Democracy firms and short Dictatorship firms. ${ }^{20}$

Note carefully that our portfolios are not long undervalued firms and short overvalued firms. Rather, within the set of overvalued firms the portfolios are long better governed and short worse governed firms.

If corporate governance is indeed more important when firms are overvalued, then we expect the significant abnormal returns in the governance hedge portfolio to be concentrated in the portfolio with firms with high industry relative valuation. In Column 1, we present result for both value-weighted (Panel A) and equal-weighted (Panel B) portfolios. We find economically and statistically significant abnormal returns for the value-weighted governance hedge portfolio with average abnormal monthly returns of 67 basis points. ${ }^{21}$

\footnotetext{
${ }^{20}$ Analogous to Gompers et al. (2003), we rebalance all portfolios in September 1990, July 1993, July 1995, and February 1998, which are the months after which new IRRC data became available. Following Giroud and Mueller (2011), in the extended sample period we rebalance in November 1999, January 2002, January 2004, and January 2006. In addition, we rebalance all portfolios each July using industry relative valuation measure computed using Compustat data in the previous year.

${ }^{21}$ This is comparable to 71 bp reported in Table V in Gompers et al. (2003). Note that because we use momentum factor from Kenneth French's website, our results on equal-weighted governance hedge portfolio are not directly comparable to Table VI in Gompers et al. (2003). Instead, they should be compared to results in Row 2 in Table IV in Giroud and Mueller (2011).
} 
In Columns (2)-(4), we examine the returns to hedge portfolios by industry relative valuation terciles. We find that the governance hedge portfolio generates statistically and economically significant monthly abnormal returns only for firms with high industry relative valuation (119 bp). Furthermore, a portfolio of firms with low or fair relative valuation that is long well-governed and short poorly-governed firms does not generate any significant abnormal returns. The results for equal-weighted portfolios are similar. Thus, governance is associated with abnormal returns only within the highly-valued set of firms.

Next, we extend the sample period to December 2006 to examine whether our results hold outside of the original Gompers et al. (2003) sample period (Columns (5)-(8)). The literature that followed Gompers et al. (2003) documents that abnormal returns to the governance hedge portfolio disappear when the sample period is extended to December 2004 (Core et al. (2006)) or December 2006 (Giroud and Mueller (2011)). In Column (5), we replicate these findings: in our sample, abnormal returns to the governance hedge portfolio over the September 1990 - December 2006 period are small and insignificant. However, the alpha of the hedge portfolio in the highest industry relative valuation tercile (Column (8)) is both statistically and economically significant. Quantitatively, the magnitude of the estimated abnormal return is remarkably similar to what we found in the original Gompers et al. (2003) sample period (108 bp vs 119 bp per month). Thus, governance still seems to matter, one just has to focus on the overvalued firms.

Previous literature had proposed several reasons why the abnormal returns to the governance hedge portfolio in the full sample have disappeared: there is some evidence that this is partly driven by "new economy" firms (Core et al. (2006)) and investors learning about the role of governance (Bebchuk, Cohen and Wang (2012)). Our results suggest a complementary explanation for why returns to the governance hedge portfolio have de- 
clined after 1999 - very few firms became highly valued during this period, especially between 2000 and 2002. In fact, in a typical year in our sample, the share of firms in the governance hedge portfolio with industry relative valuation above zero is about $55 \%$. However, in these three years this share drops to only about $20 \%$. Thus, the fact that the overall effect of holding the democracy - dictatorship portfolio over the 1990-2006 period is not different from zero may be due to the virtual absence of high misvaluation during the 2000-2002 period. Consistent with this interpretation, we find that results in Columns (6)-(8) become stronger when we exclude the 2000-2002 period: for example, in the top tercile by industry relative valuation measure, the VW alpha goes up to $134 \mathrm{bp}(\mathrm{t}=3.21)$ and the EW alpha goes up to $64 \mathrm{bp}(\mathrm{t}=2.09)$.

Finally, we address the concern that the return to the governance hedge portfolio is driven by some firm characteristics that are correlated with the GIM index but are not captured in the four-factor model in Table V. We estimate Fama-MacBeth return regressions that include the GIM index, our industry relative valuation measure, its interaction with the GIM index, and an extensive set of control variables:

$$
r_{i t}=b_{t}+b_{1} G I M_{i t-1}+b_{2} G I M_{i t-1} * M i s V_{i t-1}+b_{3} X_{i t-1}+e_{i t}
$$

where $r_{i t}$ is the return on firm $i$ 's stock in month $t, G I M_{i t}$ is either the G-index or a Dictatorship dummy, and $M i s V_{i t}$ is misvaluation proxy. $X_{i t}$ includes the level of industry relative valuation in addition to the full set of control variables used in GIM: firm size, book-to-market ratio, stock price, returns from months $t-3$ to $t-2$, from $t-6$ to $t$ 4 , and from $t-12$ to $t-7$, trading volume of NYSE or Amex stocks, trading volume of NASDAQ stocks, a NASDAQ dummy, an S\&P 500 dummy, dividend yield, sales growth over the previous five years, and institutional ownership. 
Table VI reports the results. Consistent with our model, the coefficient on the interaction term is negative and statistically significant for both the GIM index and the Dictatorship dummy. These results show that our main finding of lower abnormal returns in weak governance firms following period of high valuation is not likely to be driven by an omitted variable bias.

Overall, we find consistent evidence that shows that weak governance leads to stock market return underperformance following times when firms are highly valued, consistent with our model of time-varying managerial misbehavior. This evidence provides further support for our theory of overvaluation and corporate governance as it is hard to explain stock market underperformance with an alternative view where high relative valuation is driven by growth options and not misvaluation. Indeed, if investors valued equity correctly at all the times and anticipated differential performance by well-governed firms, then governance could be associated with lower ROA, but should not result in differential stock market performance.

Our theory, on the other hand, can explain the existence of abnormal returns to the governance hedge portfolio: to the extent that high valuation captures some overvaluation then our results suggest that overvaluation is correlated with (and potentially causing) poor managerial decisions and better governance is countering this behavior. Poor managerial decisions eventually result in worse performance - both in ROA as well as in stock market returns. More importantly, our story can explain why governance abnormal returns are time-varying (as documented in Core et al. (2006), for example): since the governance hedge portfolio outperforms only following period of overvaluation, we expect it to outperform in the second half of the 1990s when misvaluation is high for many firms in the sample, and to underperform in the subsequent years when average overvaluation subsided. In fact, as we have shown, the governance hedge portfolio that contains only 
those firms that are highly valued continues to outperform.

To summarize, the relationship between high relative prices and governance, and firm ROA and stock performance are all remarkably consistent with the theoretical idea that misvaluation causes managerial misbehavior and better governance helps counter it.

\section{Measuring Misvaluation Through Mutual Fund Flows}

Industry relative valuation is plausibly exogenous to an individual firm's valuation, but, since our measure is derived from market multiples, it is possible that times when an industry is highly valued are times with greater industry-wide growth options, rather than times of overvaluation. In the previous two sections, we challenge the idea that our results are driven by growth options and not overvaluation by considering our theoretical prediction of asymmetric effects for over and undervaluation, as well as by directly examining trading strategies that should contain alpha if our measure indeed contains overvaluation. In this section we take an alternative approach that uses a different measure of overvaluation based on mutual fund flows rather than market multiples that follows the work of Coval and Stafford (2007) and Khan et al. (2012).

Coval and Stafford (2007) develop a method to identify misvalued stocks as stocks with large fractions of trading volume from mutual funds experiencing severe outflows or inflows. Severe flows are defined as those below the 10th percentile or above the 90th percentile of incoming or outgoing assets. The authors complete a number of tests showing that these stocks under or outperform over the next 12 months. The authors note that their "empirical results provide considerable support for the view that concentrated mutual fund sales forced by capital flows exert significant price pressure in equity markets, often resulting in transactions prices far from fundamental value." 
Khan et al. (2012) build on this idea and distinguish between what they call inflow-driven buying pressure (IBP) stocks indicating overvaluation, and widespread buying pressure (WBP) stocks. The latter are experiencing significant purchases from a wide swath of mutual funds that are not receiving large inflows, and so are unlikely to be overvalued. More specifically, IBP stocks are defined as stocks subject to buying pressure by mutual funds in the top flow decile, but not subject to buying pressure from mutual funds in other flow deciles. WBP stocks are defined as stocks subject to buying pressure by all mutual funds other than those in the top decile of capital flows. Khan et al. (2012) identify about $1.5 \%$ of all mutual fund trades as IBP. They report that IBP stocks "experience a cumulative decline in market-adjusted returns of $10 \%$ over the six quarters subsequent to the buying pressure quarter." In contrast, WBP stocks experience a slight marketadjusted increase in value over the same period. The authors also find that IBP stocks have a significantly higher probability of completing seasoned equity offerings, as well as greater insider selling, and higher likelihood of equity M\&A.

Overall, these results suggests that IBP captures overvaluation, while highly valued firms, potentially with high growth options, are more likely to be indicated by WBP. Thus, if our results so far are driven by overvaluation, they should continue to hold when we replace our industry relative valuation measure with IBP. Alternatively, if our results so far reflect growth options, then they will hold if our misvaluation measure is replaced by WBP, rather than IBP. Importantly, these measures are not derived from market multiples and are based on something exogenous to the firm and its industry. ${ }^{22}$

Table VII reports the results. In Panel A, we re-run our baseline operating performance regression using the same model as Table II but replacing our measure of industry relative

\footnotetext{
${ }^{22}$ Both IBP and WBP are also uncorrelated with whether or not a firm's GIM score makes it a Democracy or a Dictatorship. Correlation of the Dictatorship dummy with IBP: -0.027 (p-value of 0.20) and with WBP: -0.002 (p-value of 0.92).
} 
valuation with a dummy for whether the firm's stock was subject to either inflow-driven (IBP) or widespread (WBP) buying pressure. IBP and WBP dummies are constructed at quarterly frequency, so we convert them to annual observations by taking the sum of respective dummies over the previous calendar year. Thus, this measure captures the intensity of mutual fund buying pressure. ${ }^{23}$ By construction, the sample of firms with stocks subject to IBP in a given year is quite small and results only in 526 firm-year observations when merged with our governance dataset. Thus, in the baseline ROA regression, we use a Dictatorship dummy as a proxy for corporate governance instead of the full GIM-index:

$$
R O A_{i j t+k}=b_{j}+b_{t}+b_{1} D_{i c t}{ }_{i j t}+b_{2} D_{i c t} t_{i j t} * B P+b_{3} X_{i j t}+e_{i j t}
$$

where $R O A_{i t+k}$ is firm $i$ 's industry (SIC3)-adjusted ROA in $k$ periods ahead of time $t$ with $k=2$ and industry indexed by $j$. The main explanatory variables are a dummy for whether the firm's GIM-index is above 14 ( Dict $\left._{i j t}\right)$, and the interaction of this dummy with either IBP (Column (2)) or WBP (Column (3)). $X_{i j t}$ includes the respective BP measure itself. In addition, as in Table II, we control for firm size, and also include year and industry fixed effects. Standard errors are adjusted for non-independence of observations within industries.

Column (2) shows results from estimating (11) using IBP as an indicator of overvaluation. Consistent with our model, the coefficient on the interaction term is negative and statistically significant ( $t$-statistic of -2.15). Quantitatively, the estimated coefficient on the interaction term implies that the gap in operating performance between weakly and strongly governed firms widens to about $2.7 \%$ following times when these firms' stock was overvalued due to buying pressure by funds with severely high inflows (IBP). This is a

\footnotetext{
${ }^{23}$ Our results are robust to using an indicator for whether the firm's stock was subject to IBP (WBP) in any of the quarters of the preceding calendar year.
} 
sizable effect given the sample average ROA of about $5 \%$, and similar to the results from using industry relative valuation in Table II. By contrast, as shown in Column (3), weak governance does not lead to either economically or statistically significant underperformance following episodes when the firm's stock was subject to widespread buying pressure (WBP).

In Panel B, we re-estimate portfolio returns from 1990-2006 as in Table V, but sort based on IBP and WBP instead of our measure of industry valuation. We first consider all firms and then look at four subsamples. Columns (2) and (3) look at overvalued $(\mathrm{IBP}=1)$ and correctly valued $(\mathrm{IBP}=0)$ stocks, while columns $(4)$ and $(5)$ look at stocks with high widespread buying pressure $(\mathrm{WBP}=1)$ and those without widespread buying pressure $(\mathrm{WBP}=0)$. These subsamples are formed based on IBP and WBP in the previous quarter. Then, in each of these subsamples we construct portfolios that are long strong governance (Democracy) firms and short weak governance (Dictatorship) firms, both value- and equal-weighted portfolios. We find positive and statistically significant alpha only in Column (2), i.e. in the sample of overvalued firms $(\mathrm{IBP}=1)$, for both valueand equal-weighted portfolios. The size of the coefficients in Column (2) are quite large, seemingly suggesting a monthly out performance of $3.72 \%$ to $5.31 \%$. However, these returns can only be earned in months when there are firms with $\mathrm{IBP}=1$ and both Dictatorship $(\mathrm{GIM} \geq 14)$ and Democracy $(\mathrm{GIM} \leq 5)$ firms. This only occurs in 45 months over the September 1990-December 2006 time frame (196 months) thus, assuming investors earn zero alpha in the other months, the average monthly alpha over this period is about a $1 / 4$ of the reported coefficients.

Overall, Table VII shows that firms that become overvalued due to mutual fund flows subsequently have significantly better ROA if they have better governance, but better governance does not correlate with future ROA in fairly valued firms. Furthermore, buying 
the stocks of overvalued firms with good governance and selling the stock of overvalued firms with poor governance produces significant positive alpha, while there is no positive alpha from a long-short portfolio based on governance in the set of firms that are not overvalued. This second measure of overvaluation is free from market value measurement and provides significant support of the idea that governance is most important when a firm becomes overvalued.

\section{Measuring Governance Through Passage of State Laws}

In this section, we address the remaining potential endogeneity concern that our results so far reflect the interaction effect of overvaluation and some unobservable firm characteristic, such as managerial quality, rather than overvaluation and governance. We follow Bertrand and Mullainathan (2003) and exploit the passage of state business combination (BC) laws as a source of exogenous variation in corporate governance. These laws, passed by states at various times between 1984 and 1991, adopted statutes that made it harder to take over any firm incorporated in the legislating state, effectively weakening corporate governance in these "treated" firms. ${ }^{24}$ Importantly, this quasi-natural experiment setting addresses the omitted variable concern since passage of a $\mathrm{BC}$ law at the state level is plausibly exogenous to any given firm's characteristics.

Based on Bertrand and Mullainathan (2003), we use a difference-in-differences approach and adopt the following specification:

$$
R O A_{i l t+k}=b_{t}+b_{i}+b_{1} M i s V_{i l t}+b_{2} B C_{l t}+b_{3} M i s V_{i l t} * B C_{l t}+b_{4} X_{i l t}+e_{i l t}
$$

\footnotetext{
${ }^{24} \mathrm{As}$ in previous literature, we only focus on the most restrictive types of antitakeover laws, the Business Combination laws. These laws impose a long-term (three to five year) moratorium on (hostile) change of control transactions, such as mergers, divestitures, consolidations, and asset sales between the firm and a large shareholder who obtains more than a specified percentage of the shares. A large empirical literature finds results consistent with increased managerial entrenchment in firms subject to BC laws (see, for example, Bertrand and Mullainathan (1999), Bertrand and Mullainathan (2003), Karpoff and Malatesta (1989), Easterbrook and Fischel (1991), Garvey and Hanka (1999), Giroud and Mueller (2011), and Atanassov (2013)). For a list of states that passed BC laws and years of passage, see Table I in Bertrand and Mullainathan (2003).
} 
where $R O A_{i l t+k}$ is firm $i$ 's ROA in $k$ periods ahead of time $t$ with $k=2$ and state of incorporation indexed by $l . B C_{j t}$ is a dummy variable that equals one if a state BC law was passed in state $l$ by time $t . X_{i j t}$ includes controls for firm size and its squared term, as well as controls for shocks at the state-year and industry-year level proxied by averages of the dependent variable across all firms in the same industry and state of location in that year, excluding the firm itself. Note that our specification includes year and firm fixed effects and we cluster standard errors at the state of incorporation level.

The innovation of our specification with respect to Bertrand and Mullainathan (2003) is that equation (12) allows for an interaction of the indicator for BC laws with relative valuation proxy, Mis $V_{i j t}$. By doing so, we effectively implement a triple difference estimator that allows us to examine whether the effect of misvaluation on operating performance changes after a state passes BC laws. In particular, the interaction term $M i s V_{i l t} * B C_{l t}$ reflects the difference in the sensitivity of future ROA to misvaluation between firms in the treated group, i.e. firms incorporated in states that passed the BC laws by time $t$, to those in the control group that includes states that never passed a BC law by time $t$, i.e. firms that never passed a BC law as well as firms that passed a BC law after time $t$. The null hypothesis is that the coefficient on the interaction term, $b_{3}$, is zero.

Our baseline estimates of (12), reported in Column (1) of Table VIII, show that overvaluation predicts weak operating performance in the future, but only for firms incorporated in states that have previously passed BC. In fact, the coefficient on the BC dummy is close to zero and not statistically significant, suggesting that the passage of BC laws has no effect on firms' operating performance in normal or undervalued times. However, consistent with all the results so far, the coefficient on the interaction term is negative and statistically significant ( $t$-statistic of -2.86). Quantitatively, the estimated coefficient on the interaction term implies that following passage of BC laws, firms incorporated in these 
states tend to underperform firms in the control group by about $0.7 \%$, or $15 \%$ of ROA sample mean, when their stock gets overvalued. As state laws are plausibly exogenous to firm characteristics, these results strongly suggest that our finding of the interaction effect between overvaluation and corporate governance is not spurious, further supporting our main hypothesis that governance is most important when a firm becomes overvalued.

One common concern with this approach has to do with reverse causality, e.g. underperforming firms potentially lobbying for the passage of the laws, especially firms in undervalued industries. Evidence in Romano (1987) suggests that BC laws have been typically adopted to protect a specific firm subject to a takeover threat, and were largely exogenous to practically all firms in the legislating state except those very few. To further address this concern, however, in Column (2) we follow Bertrand and Mullainathan (2003) and estimate (12) replacing the $B C$ dummy with a set of dummies designed to capture dynamic effects around the passage of these laws: Before $(-1)$ is a dummy variable for a firm incorporated in a state that will pass a $\mathrm{BC}$ law one year from now, Before $(0)$ is a dummy variable for a firm incorporated in a state that passed a BC law that year, After $(+1)$ is a dummy variable for a firm incorporated in a state that passed a BC law in the previous year, and After $(+2)$ is a dummy variable for a firm incorporated in a state that passed a BC law two or more years ago. ${ }^{25}$ The interaction term between Before $(-1)$ and $M i s V_{i l t}$ allows for investigation of the possibility of reverse causality since a significant coefficient would suggest that there was a more negative relation between operating performance and misvaluation in the legislating states even before the laws were enacted. Results in Column (2) show that the estimated coefficient on this term is economically and statistically insignificant. Moreover, consistent with a causal interpretation of our results, the estimated negative coefficient is strongest on the interaction of $M i s V_{i l t}$ with

\footnotetext{
${ }^{25}$ Note that since we are including an extensive set of leads and lags of the $\mathrm{BC}$ indicator on the right-hand side, we modify (12) slightly to use ROA at time $t$ as the dependent variable.
} 
After $(+1)$ and After $(+2)$ dummies.

Finally, one important source of identification in this setting is due to incomplete congruence between a firm's state of location and state of incorporation. In our sample, only about $33 \%$ of firms are located in the same state in which they are incorporated. Since $\mathrm{BC}$ laws apply to all firms in a given state of incorporation, regardless of their state of location, we can exploit this lack of congruence to address the concern that local shocks drive both the adoption of the law and the change in operating performance. To this end, we next control for the effect of any such unobservable local shocks by including a full set of state of location dummies each interacted with year dummies in the same specification as in Column (2). Effectively, this setting restricts the control group to firms located in the same state as firms in the treatment group, but incorporated in states that have not yet passed a BC law. Results, reported in Column (3), show that our results are robust to this concern.

\section{Corporate Governance, Misvaluation, and Investment}

Our results so far show that weak corporate governance firms tend to underperform following periods of high relative valuation. Performance is the result of an array of corporate decision making and thus provides compelling evidence of a difference between well governed and poorly governed firms during good times. However, the results above do not provide a channel through which governance affects performance. Gompers et al. (2003) suggests that "some combination of inefficient investment, reduced operational efficiency, or self-dealing" may result in lower performance in poorly governed firms. Our findings on performance suggest that these actions mainly occur during overvalued times. Our theory also proposes that managers make worse investment choices during overvalued times. In this section, we directly examine whether weak corporate governance firms tend 
to have different investment policies and operating efficiency than strong governance firms during periods of high relative valuation.

We start by studying whether the relation between weak governance and the amount of investment activity is more or less pronounced during periods of high relative valuation. Following Gompers et al. (2003), we examine capital expenditures (scaled by assets), the likelihood of making an acquisition in a given year, and the total number of acquisitions in a year. In addition, we examine investments in $R \& D$ since such investments can also affect future performance. We use the same empirical specification as our baseline regression (9) adding controls for lagged Tobin's q and lagged cash flow as standard in the large empirical literature on investment (see, for example, Fazzari, Hubbard and Petersen (1988)). Following Gompers et al. (2003), we estimate median regressions for capital expenditures and R\&D, negative Poisson regressions for acquisition count, and probit regressions for acquisition probability.

Table IX reports the results. The coefficient on the non-interacted GIM term corresponds to observations with relative valuation of zero, i.e. firms that are fairly valued. Consistent with the results in Gompers et al. (2003), the point estimate on GIM index in Columns (1)-(3) is positive and statistically significant suggesting that weak governance firms on average have higher levels of capital expenditures and engage in more acquisitions. The point estimate on the non-interacted GIM index in Column (4) (R\&D) is negative but not statistically significant, consistent with Giroud and Mueller (2011). Turning to the interaction term, the point estimate is not statistically significant in any specification except for acquisition count where it is significant only weakly at a $10 \%$ level. Thus, while all types of investments increase in times of high relative valuation, they do so similarly for both high and low GIM firms. ${ }^{26}$ These results imply that the underperformance of

\footnotetext{
${ }^{26}$ The increase in acquisition additivity during good times matches the original findings of Rhodes-Kropf et al.
} 
weak governance firms after periods of high relative valuation is not driven by under- or over-investment. It does not seem like the agency costs of overvaluation relate to empire building.

We next examine operating efficiency. If periods of high relative valuation bring about investment in inefficient projects (or other poor decisions) in weak governance firms, their operating efficiency should diverge from that of strong governance firms during such periods. Our model suggests that overvaluation leads to an increase in managers choosing lower value pet projects with higher private benefits. We measure operating efficiency with proxies for productivity (labor productivity measured as the log of (deflated) sales scaled by total employment) and cost inefficiency (cost of goods sold scaled by sales and $\log$ of (deflated) wages scaled by total employment). In addition, we study cumulative sales growth over the following two years. We estimate all these measures using panel regressions analogous to (9) and same controls as in Table IX. All dependent variables are trimmed at 5th and 95th percentile of their sample distribution to reduce the impact of outliers.

Table X reports the results. Across all measures of operating efficiency, higher values of the GIM index are associated with lower efficiency: the coefficient on the non-interacted GIM term suggests that, on average, weak governance firms have lower labor productivity, greater cost inefficiency (COGS and wages), and lower sales growth. However, this relation is statistically significant only in labor productivity regression. By contrast, the interaction term between the GIM index and our industry relative valuation measure is significant in all regressions except wages. ${ }^{27}$ The coefficients on the interaction term suggest that the

${ }^{27}$ In fact, none of the regressors are significant in the wages regression. This is most probably due to the fact that coverage of wage data in Compustat is very sparse making the sample substantially smaller (about 1200 observations). In addition, coverage is spotty across time even within reporting firms. Overall, the data on wages is very noisy resulting in very imprecise estimates.
} 
operating inefficiency of weak governance firms relative to strong governance firms tends to worsen during periods of high relative valuation.

Overall, the evidence in this section suggests that all firms tend to expand (increase their investment in capital expenditures and $\mathrm{R} \& \mathrm{D}$ and make more acquisitions) in times of high relative valuation. However, managers of firms with weak governance are more likely to undertake inefficient projects that lead to lower sales growth, lower labor productivity, greater cost inefficiency, and to eventual operating underperformance. These results are consistent with our idea that strong corporate governance helps curb the tendency for managers to behave poorly during periods of high relative valuation.

\section{Conclusion}

Jensen (2005) and Bolton et al. (2006) and others argue that overvaluation is the root cause of managerial misbehavior and thus agency costs are highest at the top of the cycle. At the same time, we know from Manne (1965), Gompers et al. (2003), Bertrand and Mullainathan (2003) and others that corporate governance is important in countering managerial misbehavior. If overvaluation causes managerial misbehavior and governance counters managerial misbehavior then governance should have a larger effect on firms when they are overvalued. We test this simple yet powerful idea.

Previous work has looked at the role of governance without controlling for valuation and thus found results that blended times, industries or firms where governance was countering overvaluation with those where it was not. Our findings suggests that governance may be most important during times that the firm is valued too highly since that is when agency costs are at their worst.

Our empirical work implements joint tests of the perverse effects of overvaluation and the ability of governance to counteract them. Our findings provide support for the ideas 
from both literatures, suggesting that overvaluation may cause poor managerial decisions and that governance may counter it. Our work suggests that boards and shareholders looking to create long-run value need to increase vigilance and oversight during times when the firm's stock is outperforming.

Overall this paper is the first we know of to examine when governance matters. The time-varying nature of our results are remarkably strong and suggest the need to alter how we think about the importance and impacts of governance. 


\section{REFERENCES}

Atanassov, Julian (2013) 'Do hostile takeovers stifle innovation? evidence from antitakeover legislation and corporate patenting.' Journal of Finance 68, 1097 - 1133

Baker, Malcolm, and Jeff Wurgler (2002) 'Market timing and capital structure.' Journal of Finance 57, 1-32

Baker, Malcolm, Jeremy Stein, and Jeff Wurgler (2003) 'When does the market matter? stock prices and the investment of equity-dependent firms.' Quarterly Journal of Economics 118, 969-1006

Barberis, Nicholas, and Richard H. Thaler (2003) 'A survey of behavioral finance.' In Handbook of the Economics of Finance, ed. George Constantinides, Milton Haris, and Rene M. Stulz (Amsterdam, North Holland: MacMillan)

Bebchuk, Lucian A., Alma Cohen, and Allen Ferrell (2009) 'What matters in corporate governance?' Review of Financial Studies 22, 783-827

Bebchuk, Lucian A., Alma Cohen, and Charles C. Y. Wang (2012) 'Learning and the disappearing association between governance and returns.' Journal of Financial Economics, forthcoming

Bebchuk, Lucian A., and Alma Cohen (2005) 'The costs of entrenched boards.' Journal of Financial Economics 78, 409-433

Bertrand, Marianne, and Sendhil Mullainathan (1999) 'Is there discretion in wage setting? a test using takeover legislation.' RAND Journal of Economics 30, 535 - 554

_ (2003) 'Enjoying the quiet life? corporate governance and managerial preferences.' Journal of Political Economy 111, 1043 - 1075

Bolton, Patrick, Jose Scheinkman, and Wei Xiong (2005) 'Pay for short-term performance: Executive compensation in speculative markets.' Journal of Corporation Law

_ (2006) 'Executive compensation and short-termist behavior in speculative markets.' Review of Economic Studies 73, 577-610

Campello, Murillo, and John R. Graham (2013) 'Do stock prices influence corporate decisions? evidence from the technology bubble.' Journal of Financial Economics 107(1), 89-110

Chernenko, Sergey, C. Fritz Foley, and Robin Greenwood (2012) 'Agency costs, mispricing, and ownership structure.' Harvard University working paper 
Core, John, Wayne Guay, and Tjomme Rusticus (2006) 'Does weak governance cause weak stock returns? an examination of firm operating performance and investors expectations.' Journal of Finance 61(2), 655-687

Coval, Joshua, and Erik Stafford (2007) 'Asset firesales (and purchases) in equity markets.' Journal of Financial Economics 86, 479 - 512

Cremers, Martijn K.J., and Allen Ferrell (2012) 'Thirty years of shareholder rights and firm valuation.' Harvard Law School working paper

Cremers, Martijn K.J., and Vinay B. Nair (2005) 'Governance mechanisms and equity prices.' Journal of Finance 60(6), 2859-2894

Derrien, Franois, Ambrus Kecsks, and David Thesmar (2012) 'Investor horizons and corporate policies.' Journal of Financial and Quantitative Analysis, forthcoming

Easterbrook, Frank H., and Daniel R. Fischel (1991) The Economic Structure of Corporate Law (Boston: Harvard University Press)

Fazzari, Steven M., R. Glenn Hubbard, and Bruce C. Petersen (1988) 'Financing constraints and corporate investment.' Brookings Paper on Economic Activity 1, 141-195

Garvey, Gerald T., and Gordon Hanka (1999) 'Capital structure and corporate control: The effect of antitakeover statutes on firm leverage.' Journal of Finance 54, 519 - 546

Gilchrist, S., Charlie Himmelberg, and Gur Huberman (2005) 'Do stock price bubbles influence corporate investment?' Journal of Monetary Economics 52, 805-827

Giroud, Xavier, and Holger M. Mueller (2011) 'Corporate governance, product market competition, and equity prices.' Journal of Finance 66(2), 563-600

Goldman, Eitan, and Steve Slezak (2006) 'An equilibrium model of incentive contracts in the presence of information manipulation.' Journal of Financial Economics 80, 603 626

Gompers, Paul A., Joy L. Ishii, and Andrew Metrick (2003) 'Corporate governance and equity prices.' Quarterly Journal of Economics 118(1), 107-55

Greenwald, Bruce, Joesph Stiglitz, and A. Weiss (1984) 'Informational imperfections in the capital market and macroeconomic fluctuations.' American Economic Review 74, 194 199

Hand, John R. M. (2003) 'Profits, losses and the nonlinear pricing of internet stocks.' In Intangible Assets: Values, Measures and Risks, ed. John R. M. Hand and Baruch Lev (Oxford: Oxford University Press) 
Harford, Jarrad, Sattar A. Mansi, and William F. Maxwell (2008) 'Corporate governance and firm cash holdings in the us.' Journal of Financial Economics 87, 535 - 555

Hertzel, Michael G., and Zhi Li (2010) 'Behavioral and rational explanations of stock price performance around seos: Evidence from a decomposition of market-to-book ratios.' Journal of Financial and Quantitative Analysis 45(4), 935-958

Hirshleifer, David (2001) 'Investor psychology and asset pricing.' The Journal of Finance 56(4), 1533-1597

Hoberg, Gerald, and Gordon M. Phillips (2010) 'Real and financial industry booms and busts.' Journal of Finance pp. $45-86$

Holmstrom, Bengt, and Jean Tirole (1997) 'Financial intermediation, loanable funds, and the real sector.' The Quarterly Journal of Economics 112(3), 663-691

Huson, Mark R., Paul H. Malatesta, and Robert Parrino (2004) 'Managerial succession and firm performance.' Journal of Financial Economics 74, 237-275

Jensen, Michael (2005) 'Agency costs of overvalued equity.' Financial Management $34(1), 5-19$

Kadyrzhanova, Dalida, and Matthew Rhodes-Kropf (2011) 'Concentrating on governance.' Journal of Finance 66(5), 1649-1685

Karpoff, Jonathan M., and Paul H. Malatesta (1989) 'The wealth effects of secondgeneration state takeover legislation.' Journal of Financial Economics 25, 291 - 322

Keynes, John Maynard (1936) The General Theory of Employment, Interest, and Money (London: Macmillan)

Khan, Mozaffar, Leonid Kogan, and George Serafeim (2012) 'Mutual fund trading pressure: Firm-level stock price impact and timing of seos.' Journal of Finance 67, 1371 1395

Kindleberger, Charles P. (1978) Manias, Panics, and Crashes (New York: Basic Books)

Kumar, Praveen, and Nisan Langberg (2009) 'Corporate fraud and investment distortions in efficient capital markets.' RAND Journal of Economics 40, 144 - 172

Manne, Henry (1965) 'Mergers and the market for corporate control.' Journal of Political Economy 73,110

Masulis, Ronald W., Cong Wang, and Fei Xie (2007) 'Corporate governance and acquirer returns.' Journal of Finance 62(4), 1851-1889 
Morck, Randall, Andrei Shleifer, and Robert W. Vishny (1990) 'The stock market and investment: Is the market a sideshow.' Brookings Papers on Economic Activity 2, 157 215

Myers, Stewart C., and N. S. Majluf (1984) 'Corporate financing and investment decisions when firms have information that investors do not have.' Journal of Financial Economics $13,187-221$

Panageas, Stavros (2005) 'The neoclassical theory of investment in speculative markets.' Wharton working paper

Pastor, Lubos, and Pietro Veronesi (2009) 'Technological revolutions and stock prices.' American Economic Review 99, 1451-1483

Polk, Christopher, and Paola Sapienza (2009) 'The stock market and corporate investment: a test of catering theory.' Review of Financial Studies 22(1), 187-217

Rhodes-Kropf, Matthew, and S. Viswanathan (2004) 'Market valuation and merger waves.' Journal of Finance 59, 2685-2718

Rhodes-Kropf, Matthew, David Robinson, and S. Viswanathan (2005) 'Valuation waves and merger activity: The empirical evidence.' Journal of Financial Economics 77, 561603

Romano, Roberta (1987) 'The political economy of takeover statutes.' Virginia Law Review $73,111-199$

Scharfstein, David (1988) 'The disciplinary role of takeovers.' The Review of Economic Studies 55(2), 185-199

Shleifer, Andrei (2000) Inefficient Markets-An Introduction to Behavioral Finance, 1st ed. (Oxford: Oxford University Press)

Shleifer, Andrei, and Robert W. Vishny (2003) 'Stock market driven acquisitions.' Journal of Financial Economics 70(3), 295-311

Stein, Jeremy C. (1996) 'Rational capital budgeting in an irrational world.' Journal of Business 69, 429-455

Welch, Ivo (2004) 'Capital structure and stock returns.' Journal of Political Economy $112,106-131$

Wooldridge, Jeffrey M. (2002) Econometric Analysis of Cross-section and Panel Data (The MIT Press)

Yun, Hayong (2009) 'The choice of corporate liquidity and corporate governance.' Review of Financial Studies 22(4), 1447-1475 


\section{Table I: Summary Statistics}

This table displays summary statistics of all variables in the sample (Panel A), the correlations of these variables with industry relative valuation measure (Panel B), and the joint distribution of the main governance proxy and the relative valuation proxy (Panel $\mathrm{C}$ ). To compute relative valuation, we start by estimating total relative valuation (Total RelVal) measured as the difference between a firms actual (log) market value of equity in year $\mathrm{t}$ and one implied a valuation model estimated by regressing market value of equity on book equity, net income, and leverage. The valuation predictive regressions are run at the 3-digit SIC industry level every year using firm observations from years t-10 to t-1 for all firms in the Compustat universe. The three-digit SIC industry average of these differences (excluding firm $i$ ) is our measure of industry relative valuation (Industry RelVal). The governance measures are based on the sample of 2,023 firms from the ISS Riskmetrics database in the 1990 to 2006 period. GIM-index is the index of 24 provisions from Gompers et al. (2003). Dictatorship firms have values of the GIM index of at least 14 . Democracy firms have values of the GIM index of at most 5. ROA is operating income after depreciation scaled by year-end total assets. It is industry-adjusted each year by subtracting median ROA in three-digit SIC industry. Firm size is the logarithm of the book value of assets. Industry HHI is defined as the sum of the squares of the individual company market shares for all the companies in the three-digit SIC industry. For additional details on variable definitions and sources see Appendix B.

Panel A: Summary Statistics

\begin{tabular}{lccc}
\hline \hline \multicolumn{1}{c}{ Variable } & & & \\
\multicolumn{1}{c}{ Mean } & Median & Std Dev \\
\hline Total Relative Valuation & & & \\
Industry Relative Valuation & 0.04 & 0.01 & 0.63 \\
& 0.04 & 0.06 & 0.24 \\
GIM & & & \\
Share of Democracy Firms (GIM $<=5)$ & 9.21 & 9 & 2.71 \\
Share of Dictatorship Firms $(\mathrm{GIM}>=14)$ & 0.11 & 0 & 0.31 \\
& 0.05 & 0 & 0.22 \\
Industry-adjusted ROA & & & \\
Firm Size & 0.05 & 0.04 & 0.13 \\
Industry HHI & 7.10 & 6.92 & 1.52 \\
\hline
\end{tabular}


Panel B: Correlations with Relative Valuation Measures

\begin{tabular}{lc}
\hline \hline Variable & $\begin{array}{c}\text { Correlation with } \\
\text { Industry RelVal }\end{array}$ \\
\hline GIM & 0.01 \\
Share of Democracy Firms $(\mathrm{GIM}<=5)$ & 0.01 \\
Share of Dictatorship Firms $(\mathrm{GIM}>=14)$ & 0.01 \\
Firm Size & -0.001 \\
Industry HHI & -0.01 \\
\hline
\end{tabular}

Panel C: Empirical Distribution of the G-index across industry relative valuation terciles

\begin{tabular}{lccc}
\hline \hline & \multicolumn{3}{c}{ Industry RelVal } \\
\cline { 2 - 4 } & $\begin{array}{c}\text { Lowest } \\
\text { Tercile }\end{array}$ & $\begin{array}{c}\text { Medium } \\
\text { Tercile }\end{array}$ & $\begin{array}{c}\text { High } \\
\text { Tercile }\end{array}$ \\
& & & \\
\hline & 8.86 & 9.01 & 9.00 \\
Mean GIM index & 9 & 9 & 9 \\
Median GIM index & $(2,19)$ & $(2,19)$ & $(2,18)$ \\
\hline
\end{tabular}




\section{Table II: Operating Performance}

This table reports results for OLS regressions of 2-year ahead industry (SIC3)-adjusted operating performance (ROA) on governance and its interaction with measures of relative valuation. Governance is measured by the shareholder rights index from Gompers et al. (2003) (GIM). In Column (1), the GIM index is not interacted with relative valuation measures. In Columns (2) and (3), the GIM index is interacted with measures of industry and total relative valuation, respectively. In Column (4), the sample is restricted Democracy (GIM $\leq 5)$ and Dictatorship ( GIM $\geq 14)$ firms and governance is measured by a dummy for Dictatorship firms. Controls for firm size (log of the book value of assets), and year and industry fixed effects are included in all regressions. Coefficients on these variables are omitted from the table for brevity and are available upon request. Variable definitions are in Table I and Appendix B. t-statistics based on robust standard errors clustered at industry level are in parentheses. Levels of significance are indicated by $*, * *$, and $* * *$ for $10 \%, 5 \%$, and $1 \%$ respectively.

\begin{tabular}{|c|c|c|c|c|}
\hline \multicolumn{5}{|c|}{ Dependent Variable: Industry-adjusted $\mathrm{ROA}_{t+2}$} \\
\hline $\operatorname{GIM}_{t}$ & $\begin{array}{c}-0.001^{* * *} \\
(-2.70)\end{array}$ & $\begin{array}{c}-0.001^{* *} \\
(2.24)\end{array}$ & $\begin{array}{c}-0.0004 \\
(-0.02)\end{array}$ & \\
\hline Industry RelVal $t$ & & $\begin{array}{c}0.058^{* * *} \\
(4.46)\end{array}$ & & \\
\hline Industry RelVal ${ }^{*} \mathrm{GIM}_{t}$ & & $\begin{array}{c}-0.004^{* * *} \\
(-2.67)\end{array}$ & & \\
\hline Total RelVal $t$ & & & $\begin{array}{c}0.106^{* * *} \\
(8.63)\end{array}$ & \\
\hline Total RelVal $t$ GIM $_{t}$ & & & $\begin{array}{c}-0.003^{* *} \\
(-2.12)\end{array}$ & \\
\hline Dictatorship $t$ & & & & $\begin{array}{c}-0.019^{* * *} \\
(-2.98)\end{array}$ \\
\hline Industry RelVal $t$ & & & & $\begin{array}{l}0.026^{*} \\
(1.82)\end{array}$ \\
\hline Industry RelVal $t^{*}$ Dictatorship $t$ & & & & $\begin{array}{c}-0.049^{* *} \\
(-2.37)\end{array}$ \\
\hline Firm Size $t$ & $\begin{array}{c}0.014^{* * *} \\
(21.15)\end{array}$ & $\begin{array}{c}0.009^{* * *} \\
(5.79)\end{array}$ & $\begin{array}{c}0.009^{* * *} \\
(2.19)\end{array}$ & $\begin{array}{c}0.013^{* * *} \\
(5.97)\end{array}$ \\
\hline Year Fixed Effects & Yes & Yes & Yes & Yes \\
\hline Industry Fixed Effects & Yes & Yes & Yes & Yes \\
\hline Adjusted- $\mathrm{R}^{2}$ & 0.34 & 0.34 & 0.41 & 0.31 \\
\hline Observations & 15046 & 15046 & 15046 & 2143 \\
\hline
\end{tabular}




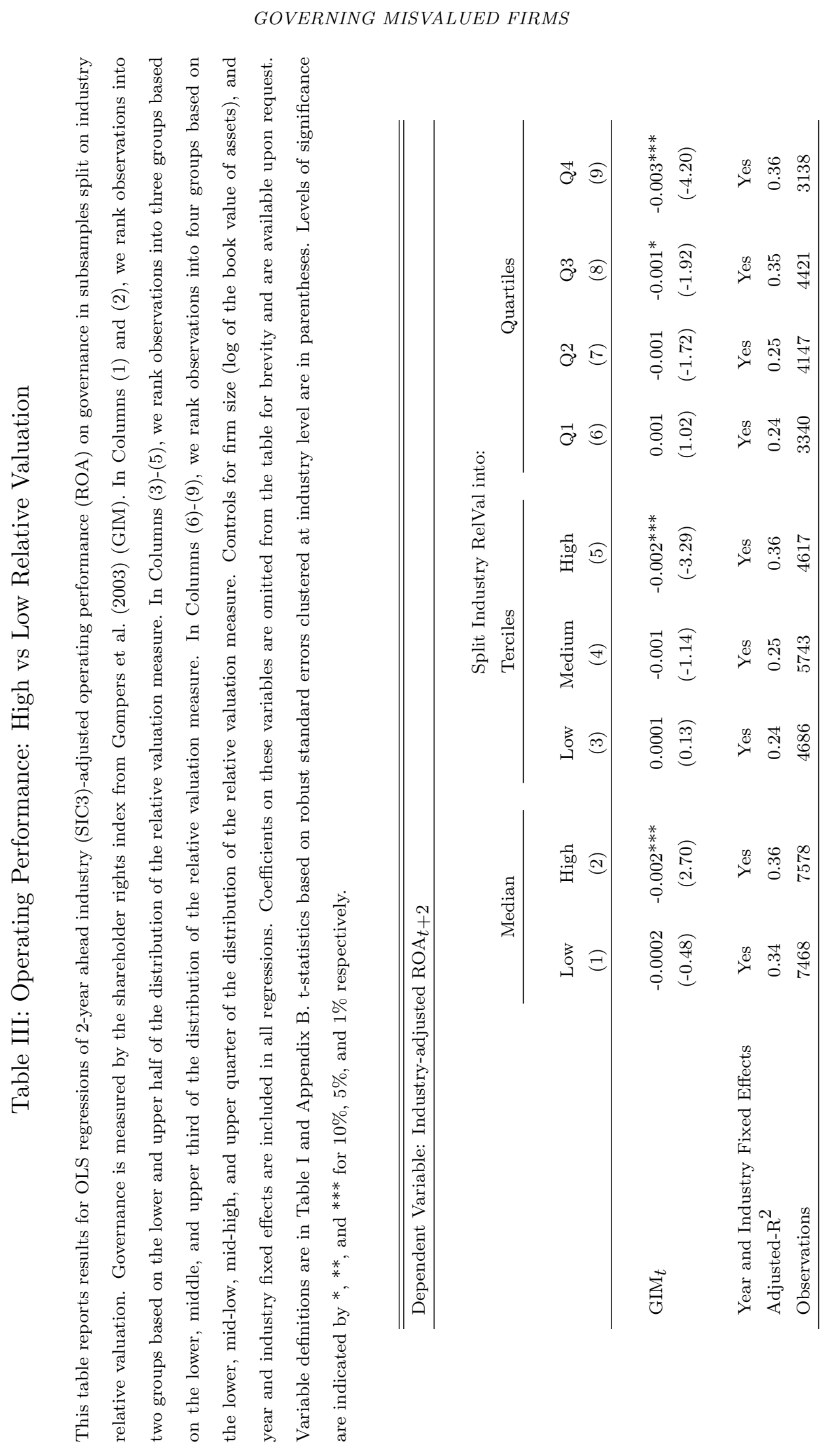



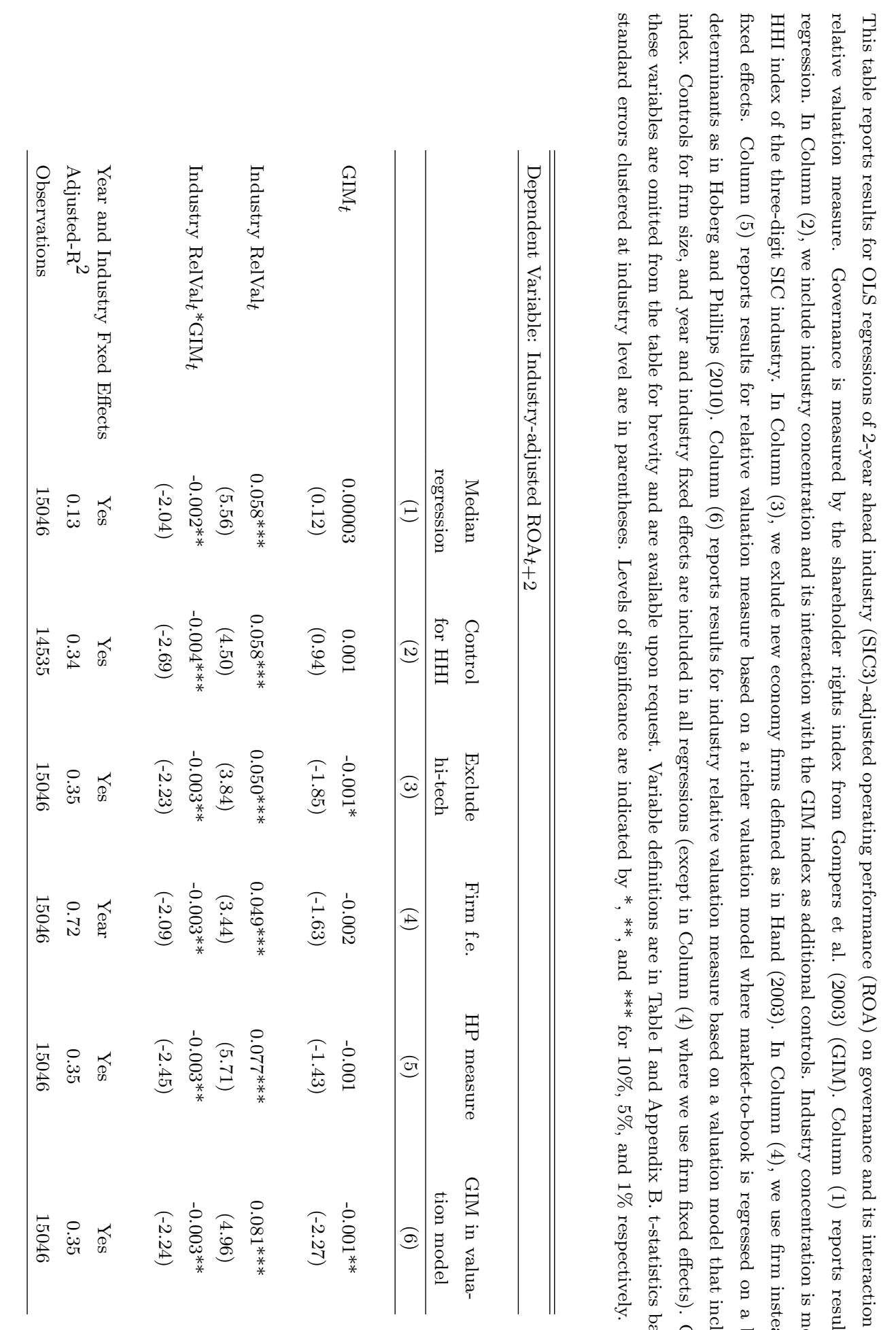

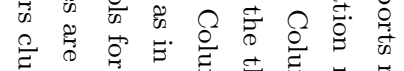

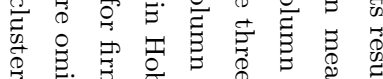

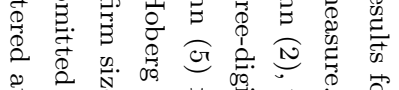

\&.

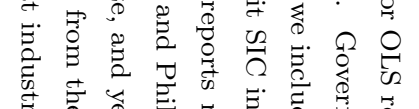

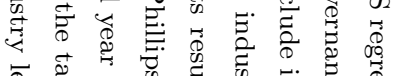

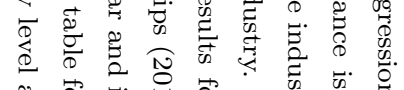

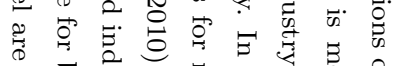

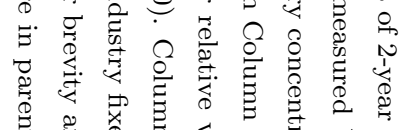

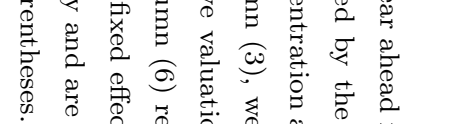

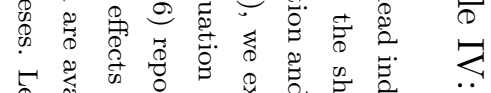

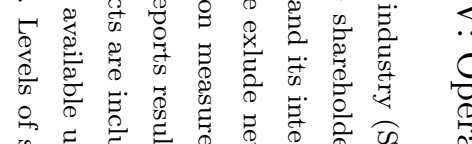

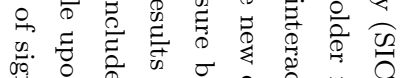

哭.

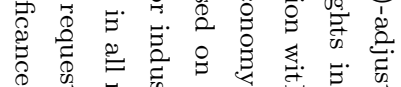

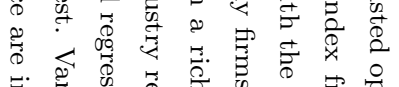

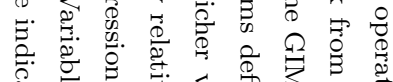

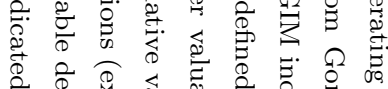

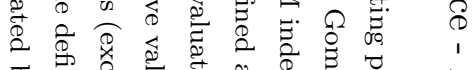

व

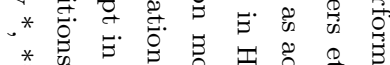

**

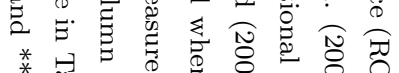

*

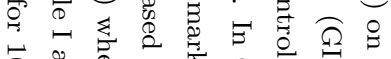

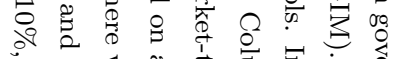

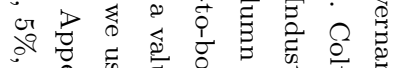

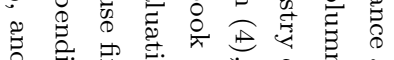

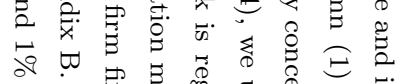

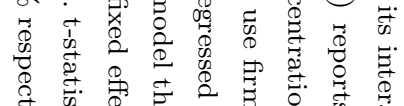

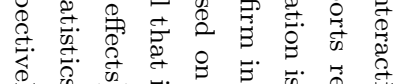

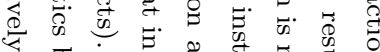

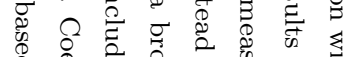

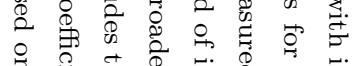

马

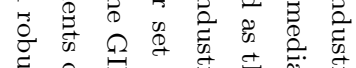

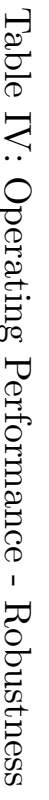

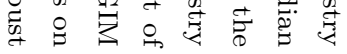


GOVERNING MISVALUED FIRMS

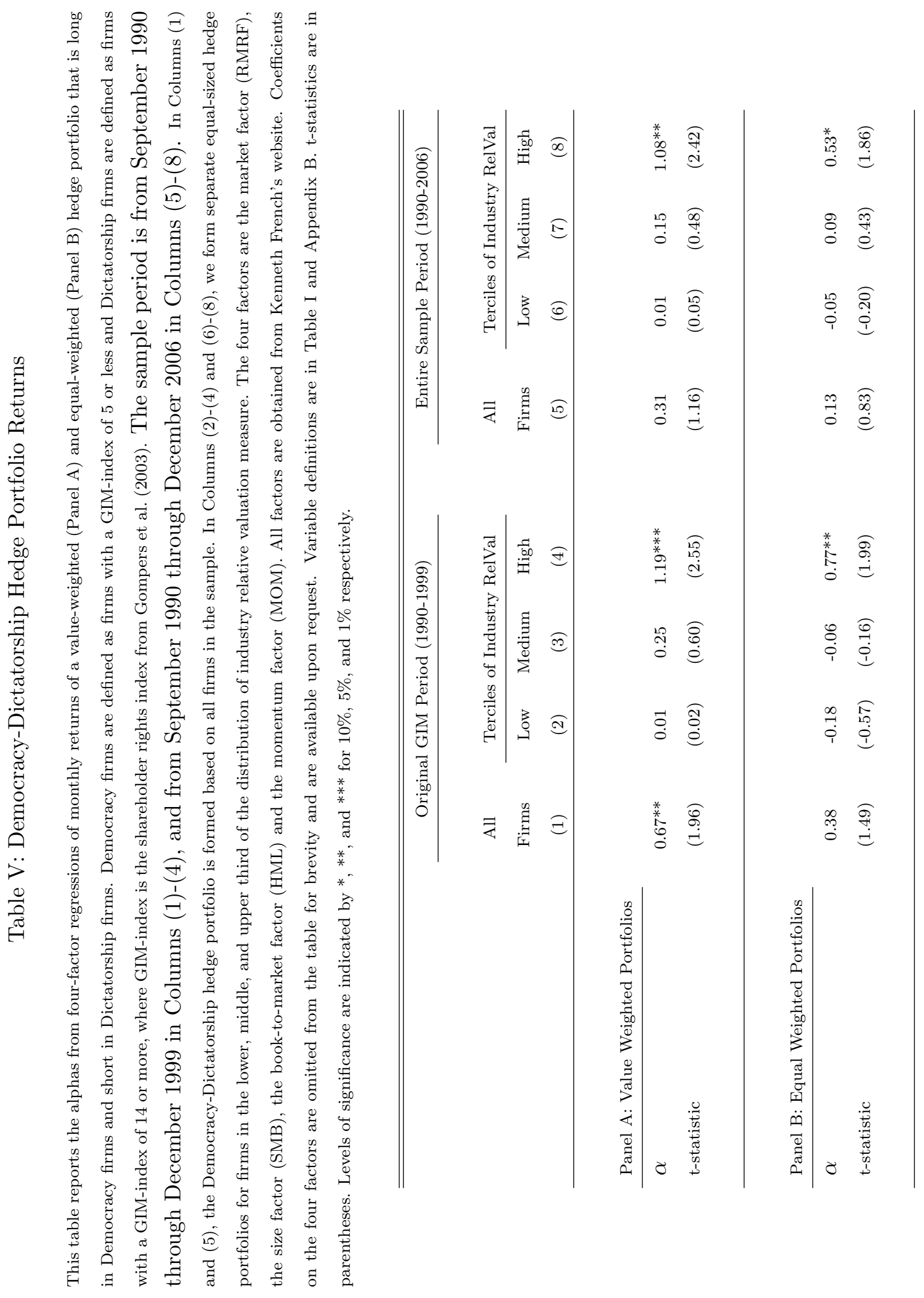




\section{Table VI: Fama-MacBeth Return Regressions}

This table reports the Fama-MacBeth coefficients from 112 monthly cross-sectional regressions of individual stock returns on governance, its interaction with industry relative valuation measure, and controls. In Column (1), governance is measured by the shareholder rights index from Gompers et al. (2003) (GIM). In Column (2), the sample is restricted Democracy $(\mathrm{GIM} \leq 5)$ and Dictatorship $(\mathrm{GIM} \geq 14)$ firms and governance is measured by a dummy for Dictatorship firms. As in Gompers et al. (2003), we include controls for lagged firm size, book-to-market ratio, stock price, returns from months t-3 to t-2, from t-6 to t-4, and from t-12 to t-7, trading volume of NYSE or Amex stocks, trading volume of NASDAQ stocks, a NASDAQ dummy, an S\&P 500 dummy, dividend yield, sales growth over the previous five years, and institutional ownership. Coefficients on these variables are omitted from the table for brevity and are available upon request. Variable definitions are in Table I and Appendix B. The sample period is from September 1990 through December 1999. t-statistics are in parentheses. Levels of significance are indicated by $* * *$, and $* * *$ for $10 \%, 5 \%$, and $1 \%$ respectively.

\begin{tabular}{|c|c|c|}
\hline \multicolumn{3}{|l|}{ Dependent Variable: Return $t$} \\
\hline & (1) & $(2)$ \\
\hline $\operatorname{GIM}_{t-1}$ & $\begin{array}{l}0.000 \\
(0.04)\end{array}$ & \\
\hline Industry RelValt-1 & $\begin{array}{c}0.054^{* * *} \\
(9.77)\end{array}$ & \\
\hline Industry $\operatorname{RelVal}_{t-1} * \mathrm{GIM}_{t-1}$ & $\begin{array}{c}-0.001^{* *} \\
(-2.38)\end{array}$ & \\
\hline Dictatorship $t-1$ & & $\begin{array}{l}0.001 \\
(0.28)\end{array}$ \\
\hline Industry RelVal $t-1$ & & $\begin{array}{c}0.046^{* * *} \\
(8.69)\end{array}$ \\
\hline Industry RelVal $_{t-1} *$ Dictatorship $_{t-1}$ & & $\begin{array}{c}-0.015^{* *} \\
(-1.96)\end{array}$ \\
\hline Months & 112 & 112 \\
\hline
\end{tabular}




\section{Table VII: Mutual Fund Buying Pressure}

This table reports results of regressions that examine the effect of governance on operating (Panel A) and stock market (Panel B) performance of firms whose stock was subject to overvaluation following inflow-driven mutual fund buying pressure. The measures of mutual fund buying pressure are from Khan et al. (2012): an indicator for stocks subject to inflow-driven buying pressure (IBP) by mutual funds in the top decile of capital flows and an indicator for stocks subject to widespread buying pressure (WBP) by mutual funds not experiencing significant flows. The sample is restricted to Democracy $(\mathrm{GIM} \leq 5)$ and Dictatorship (GIM $\geq 14)$ firms, where GIM-index is the shareholder rights index from Gompers et al. (2003). Panel A reports results for OLS regressions of 2-year ahead industry (SIC3)-adjusted operating performance (ROA) on a dummy for Dictatorship firms and its interaction with IBP and WBP. In Column (1), the Dictatorship dummy is not interacted with IBP or WBP. In Columns (2) and (3), the Dictatorship dummy is interacted with measures of flow-motivated (IBP) vs information-motivated buying pressure (WBP), respectively. Controls for firm size (log of the book value of assets), and year and industry fixed effects are included in all regressions. Variable definitions are in Table I and Appendix B. t-statistics based on robust standard errors clustered at industry level are in parentheses. Panel B reports the alphas from four-factor regressions of monthly returns of a value-weighted (VW) and equal-weighted (EW) hedge portfolio that is long in Democracy firms and short in Dictatorship firms. In Column (1), the Democracy-Dictatorship hedge portfolio is formed based on all firms in the sample. In Columns (2)-(3), we form separate hedge portfolios for firms were subject to IBP in the previous quarter (Column (2)) and those that were not (Column (3)). In Columns (4)-(5), we form separate hedge portfolios for firms that were subject to WBP in the previous quarter (Column (4)) and those that were not (Column (5)). The four factors are the market factor (RMRF), the size factor (SMB), the book-to-market factor (HML) and the momentum factor (MOM). All factors are obtained from Kenneth French's website. Coefficients on the four factors are omitted from the table for brevity and are available upon request. The sample period is from September 1990 through December 2006. t-statistics are in parentheses. Levels of significance are indicated by *, **, and $* * *$ for $10 \%, 5 \%$, and $1 \%$ respectively. 
Panel A: ROA

\begin{tabular}{|c|c|c|c|}
\hline \multicolumn{4}{|c|}{ Dependent Variable: Industry-adjusted $\mathrm{ROA}_{t+2}$} \\
\hline & $(1)$ & $(2)$ & $(3)$ \\
\hline \multirow[t]{2}{*}{ Dictatorship $t$} & $-0.019 * *$ & -0.017 & $-0.018^{*}$ \\
\hline & $(-2.17)$ & $(-1.58)$ & $(-1.68)$ \\
\hline \multirow[t]{2}{*}{$\mathrm{IBP}_{t}$} & & $0.017^{*}$ & \\
\hline & & $(1.67)$ & \\
\hline \multirow[t]{2}{*}{$\mathrm{IBP}_{t} *$ Dictatorship $t$} & & $-0.027 * *$ & \\
\hline & & $(-2.15)$ & \\
\hline \multirow[t]{2}{*}{$\mathrm{WBP}_{t}$} & & & 0.007 \\
\hline & & & $(0.95)$ \\
\hline \multirow[t]{2}{*}{$\mathrm{WBP}_{t} *$ Dictatorship $t$} & & & -0.004 \\
\hline & & & $(-0.36)$ \\
\hline \multirow[t]{2}{*}{ Firm Size $t$} & $0.012^{* *}$ & $0.012^{* *}$ & $0.012^{* *}$ \\
\hline & $(2.08)$ & $(2.10)$ & $(2.09)$ \\
\hline Year Fixed Effects & Yes & Yes & Yes \\
\hline Industry Fixed Effects & Yes & Yes & Yes \\
\hline Adjusted-R ${ }^{2}$ & 0.30 & 0.30 & 0.30 \\
\hline Observations & 2143 & 2143 & 2143 \\
\hline
\end{tabular}

Panel B: Democracy-Dictatorship Hedge Portfolio Returns: Entire Sample (1990-2006)

\begin{tabular}{|c|c|c|c|c|c|}
\hline & $\begin{array}{l}\text { All } \\
\text { Firms } \\
(1)\end{array}$ & $\begin{array}{c}\mathrm{IBP}=1 \\
(2)\end{array}$ & $\begin{array}{c}\mathrm{IBP}=0 \\
(3)\end{array}$ & $\begin{array}{c}\mathrm{WBP}=1 \\
(4)\end{array}$ & $\begin{array}{c}\mathrm{WBP}=0 \\
(5)\end{array}$ \\
\hline $\begin{array}{l}\alpha(\mathrm{VW}) \\
\text { t-statistic }\end{array}$ & $\begin{array}{c}0.31 \\
(1.16)\end{array}$ & $\begin{array}{c}5.32^{* * *} \\
(2.80)\end{array}$ & $\begin{array}{c}0.26 \\
(1.27)\end{array}$ & $\begin{array}{c}1.41 \\
(1.49)\end{array}$ & $\begin{array}{c}0.21 \\
(0.99)\end{array}$ \\
\hline $\begin{array}{l}\alpha(\mathrm{EW}) \\
\text { t-statistic }\end{array}$ & $\begin{array}{c}0.13 \\
(0.83)\end{array}$ & $\begin{array}{c}3.72^{* *} \\
(2.04)\end{array}$ & $\begin{array}{c}0.15 \\
(0.95)\end{array}$ & $\begin{array}{c}0.78 \\
(1.02)\end{array}$ & $\begin{array}{c}0.14 \\
(0.84)\end{array}$ \\
\hline
\end{tabular}




\section{Table VIII: Operating Performance around State Laws}

This table reports results for the difference-in-differences estimator using staggered passages of state business combination (BC) laws. The sample is a panel of all firms in Compustat, excluding firms in financial and utilities sectors, from 1977 to 1995 . BC is a dummy that equals one if the firm is incorporated in a state that passed a BC law by year $t$. State BC law passage years are from Bertrand and Mullainathan (2003). Data on states of incorporation and state of location are from historical Compustat tapes. Before(-1) is a dummy for firms incorporated in states that will pass a $\mathrm{BC}$ law one year from now, Before(0) is a dummy for firms incorporated in states that passed a $\mathrm{BC}$ law that year, After $(+1)$ is a dummy for firms incorporated in states that passed a BC law in the previous year, and After $(+2)$ is a dummy for firms incorporated in states that passed a BC law two or more years ago. Controls include firm size (log of the book value of assets), its squared term, averages of the dependent variable across all firms in the same industry and state of location in that year, excluding the firm itself. All regressions control for year and firm fixed effects. In addition, Column (3) controls for state of location-year fixed effects. Coefficients on these variables are omitted from the table for brevity and are available upon request. Variable definitions are in Table I and Appendix B. t-statistics based on robust standard errors clustered at the state of incorporation level are in parentheses. Levels of significance are indicated by *, ${ }^{* *}$, and ${ }^{* * *}$ for $10 \%, 5 \%$, and $1 \%$ respectively. 


\begin{tabular}{|c|c|c|c|}
\hline Dependent Variable: & $\begin{array}{c}\mathrm{ROA}_{t+2} \\
(1)\end{array}$ & $\begin{array}{c}\mathrm{ROA}_{t} \\
(2)\end{array}$ & $\begin{array}{c}\mathrm{ROA}_{t} \\
(3)\end{array}$ \\
\hline $\mathrm{BC}$ & $\begin{array}{l}0.006 \\
(1.23)\end{array}$ & & \\
\hline Before(-1) & & $\begin{array}{l}-0.001 \\
(-0.34)\end{array}$ & $\begin{array}{l}-0.002 \\
(-0.74)\end{array}$ \\
\hline Before $(0)$ & & $\begin{array}{l}0.006 \\
(1.47)\end{array}$ & $\begin{array}{l}0.003 \\
(0.74)\end{array}$ \\
\hline After(1) & & $\begin{array}{l}0.002 \\
(0.44)\end{array}$ & $\begin{array}{l}-0.001 \\
(-0.17)\end{array}$ \\
\hline $\operatorname{After}(2+)$ & & $\begin{array}{l}0.006 \\
(1.12)\end{array}$ & $\begin{array}{l}0.001 \\
(0.14)\end{array}$ \\
\hline BC*Industry RelVal & $\begin{array}{c}-0.029 * * * \\
(-2.86)\end{array}$ & & \\
\hline Before $(-1) *$ Industry RelVal & & $\begin{array}{l}-0.009 \\
(-0.86)\end{array}$ & $\begin{array}{l}-0.003 \\
(-0.26)\end{array}$ \\
\hline $\operatorname{Before}(0)^{*}$ Industry RelVal $t$ & & $\begin{array}{l}-0.013 \\
(-1.16)\end{array}$ & $\begin{array}{l}-0.008 \\
(-0.79)\end{array}$ \\
\hline $\operatorname{After}(1)^{*}$ Industry $\operatorname{RelVal}_{t}$ & & $\begin{array}{c}-0.024^{* *} \\
(-2.15)\end{array}$ & $\begin{array}{c}-0.021^{*} \\
(-1.72)\end{array}$ \\
\hline $\operatorname{After}(2+)^{*}$ Industry $\operatorname{RelVal}_{t}$ & & $\begin{array}{c}-0.033^{* *} \\
(-2.42)\end{array}$ & $\begin{array}{c}-0.022^{* *} \\
(-2.22)\end{array}$ \\
\hline Industry RelVal $t$ & $\begin{array}{c}0.019^{* * *} \\
(2.66)\end{array}$ & $\begin{array}{c}0.051^{* * * *} \\
(4.34)\end{array}$ & $\begin{array}{c}0.044^{* * *} \\
(4.77)\end{array}$ \\
\hline Year Fixed Effects & Yes & Yes & Yes \\
\hline Firm Fixed Effects & Yes & Yes & Yes \\
\hline State-Year Fixed Effects & No & No & Yes \\
\hline Adjusted-R ${ }^{2}$ & 0.65 & 0.65 & 0.65 \\
\hline Observations & 62653 & 62653 & 62653 \\
\hline
\end{tabular}




\section{Table IX: Investment and Acquisitions}

This table reports results for panel regressions of capital expenditures, $R \& D$, and acquisition activity on governance and its interaction with industry relative valuation. Governance is measured by the shareholder rights index from Gompers et al. (2003) (GIM). In Column (1), the dependent variable is capital expenditures scaled by total assets. In Column (2), the dependent variable is the number of acquisition bids a firm makes in a given year. In Column (3), the dependent variable is the acquisition likelihood defined as a dummy variable that takes the value of one if a firm makes an acquisition bid in a given year. In Column (4), the dependent variable is R\&D expenditures scaled by sales. The dependent variables in Columns (1) and (4) are winsorized at $5 \%$ level. Controls for firm size (log of the book value of assets), Tobin's q, cash flow, and year and industry fixed effects are included in all regressions. All controls are lagged one period. Coefficients on these variables are omitted from the table for brevity and are available upon request. Variable definitions are in Appendix B. t-statistics based on robust standard errors clustered at industry level are in parentheses. Levels of significance are indicated by *, **, and *** for $10 \%, 5 \%$, and $1 \%$ respectively.

\begin{tabular}{lcccc}
\hline \hline Dependent Variable: & Capex & $\begin{array}{c}\text { Number of } \\
\text { acquisitions }\end{array}$ & $\begin{array}{c}\text { Acq } \\
\text { Dummy }\end{array}$ & R\&D \\
& $(1)$ & $(2)$ & $(3)$ & $(4)$ \\
\hline & & & & \\
GIM & $0.0005^{* * *}$ & $0.026^{* * *}$ & $0.006^{* * *}$ & -0.0003 \\
& $(4.11)$ & $(4.69)$ & $(2.59)$ & $(-0.61)$ \\
Industry RelVal & & & & \\
& $0.011^{* *}$ & $0.606^{* * *}$ & $0.136^{* *}$ & $0.018^{*}$ \\
Industry RelVal $t^{*} \mathrm{GIM}$ & $(2.07)$ & $(4.69)$ & $(2.00)$ & $(1.67)$ \\
& -0.0004 & $-0.039^{*}$ & -0.007 & -0.001 \\
& $(-0.73)$ & $(-1.75)$ & $(-1.05)$ & $(-1.26)$ \\
Year Fixed Effects & & & & \\
Industry Fixed Effects & Yes & Yes & Yes & Yes \\
& & Yes & Yes & Yes \\
Adjusted-R & & & & \\
Observations & 0.22 & 0.08 & 0.12 & 0.41 \\
\hline
\end{tabular}




\section{Table X: Operating efficiency}

This table reports results for panel regressions of measures of operating efficiency on governance and its interaction with industry relative valuation. Governance is measured by the shareholder rights index from Gompers et al. (2003) (GIM). In Column (1), the dependent variable is labor productivity defined as log of sales in 1996 dollars scaled by number of employees. In Column (2), the dependent variable is cost of goods sold scaled by sales. In Column (3), the dependent variable is log of wages in 1996 dollars scaled by number of employees. In Column (4), the dependent variable is the log of two-year ahead sales to current year's sales. All dependent variables are winsorized at $5 \%$ level. Controls for firm size (log of the book value of assets), Tobin's q, cash flow, and year and industry fixed effects are included in all regressions. All controls are lagged one period. Coefficients on these variables are omitted from the table for brevity and are available upon request. Variable definitions are in Appendix B. t-statistics based on robust standard errors clustered at industry level are in parentheses. Levels of significance are indicated by $*,{ }^{* *}$, and ${ }^{* * *}$ for $10 \%, 5 \%$, and $1 \%$ respectively.

\begin{tabular}{lcccc}
\hline \hline Dependent Variable: & Labor & Cost of & Wages & Sales \\
& Productivity & Goods Sold & & Growth \\
& $(1)$ & $(2)$ & $(3)$ & $(4)$ \\
\hline GIM & $-0.012^{* *}$ & 0.095 & 0.013 & -0.001 \\
& $(-1.98)$ & $(0.50)$ & $(1.45)$ & $(-0.55)$ \\
Industry RelVal & & & & \\
& $0.275^{* *}$ & $-6.094^{* *}$ & 0.078 & $0.300^{* * *}$ \\
Industry RelVal $t^{*}$ GIM & $(2.03)$ & $(-1.85)$ & $(0.40)$ & $(3.47)$ \\
& $-0.029^{* *}$ & $0.716^{* *}$ & -0.009 & $-0.014^{* *}$ \\
& $(-2.34)$ & $(2.18)$ & $(-0.54)$ & $(-1.97)$ \\
Year Fixed Effects & & & & \\
Industry Fixed Effects & Yes & Yes & Yes & Yes \\
& Yes & Yes & Yes & Yes \\
Adjusted-R & & & & \\
Observations & 0.63 & 0.49 & 0.25 & 0.14 \\
\hline
\end{tabular}




\section{A. Appendix}

\section{i. Proof of Proposition 1:}

If $R-\gamma(I-A) / p_{H}^{\prime} \geq B / \Delta p^{\prime}$ then from equation (3) we know the investors will invest. However if $B / \Delta p>R-\gamma(I-A) / p_{H}^{\prime}$ from equation (6) we know that the manager will choose the bad project with higher private benefits. Both inequalities in equation (7) can only hold when $\delta>0$ since $\delta \leq 0 \Rightarrow B / \Delta p \leq B / \Delta p^{\prime}$. QED

\section{ii. Proof of Corollary 1:}

$\frac{\partial B / \Delta p^{\prime}}{\partial \delta}<0$ while $\frac{\partial(B / \Delta p)}{\partial \delta}=0$, therefore $B / \Delta p-B / \Delta p^{\prime}$ increases with $\delta$ and more firms

satisfy equation $(7)$. Also, $\left(\frac{\partial \bar{A}}{\partial \delta}<0\right)$ so more firms can get financing and those firms who get financing due to overvaluation will misbehave. QED

\section{iii. Proof of Proposition 2:}

By assumption, increased corporate governance reduces the private benefits from the bad project. If the private benefits, $B$, are reduced then $B / \Delta p-B / \Delta p^{\prime}$ falls (i.e. $\frac{\partial}{\partial B}(B / \Delta p-$ $B\left(\Delta p^{\prime}\right)>0$.) Thus, when the private benefits are reduced to $b$ then only firms for which $b / \Delta p>R-\gamma(I-A) / p_{H}^{\prime} \geq b / \Delta p^{\prime}$ will misbehave - which is fewer firms since $B / \Delta p-$ $B / \Delta p^{\prime}>b / \Delta p-b / \Delta p^{\prime}$. QED

\section{B. Appendix}

The variables used in this paper are extracted from four major data sources: ISS Riskmetrics Database, COMPUSTAT, CRSP, and SDC Platinum. For each data item, we indicate the relevant source in square brackets. The specific variables used in the analysis are defined as follows:

- Governance [Riskmetrics]:

- GIM-index is the sum of all antitakeover provisions in a firm's charter that varies between 0 and 24 (Gompers et al. (2003)).

- Dictatorship is a dummy which takes the value of one for observations with GIM index of at least 14. [Riskmetrics]

- Democracy is a dummy which takes the value of one for observations with GIM index of at most 5. [Riskmetrics]

- Relative valuation:

- Total (or raw) relative valuation: the difference between a firm's actual valuation and one implied by average industry pricing using historical industry multiples. To get implied valuation, for each industry $j$ and year $t$, we first estimate a valuation model from the following industry-level regressions that use ten years of lagged data:

$$
\log M_{i j \tau}=a_{0 j t}+a_{1 j t} \log B_{i j \tau}+a_{2 j t} \log (N I)_{i j \tau}^{+}
$$




$$
\begin{gathered}
\quad+a_{3 j t} I_{(<0)} \log (N I)_{i j \tau}^{+}+a_{4 j t} L E V_{i j \tau}+\varepsilon_{i j \tau}, \\
\tau=t-10, \ldots, t-1
\end{gathered}
$$

where $i$ indexes firms, $j$ indexes industries, and $t$ indexes time. $M_{i j t}$ is the market value of equity, computed by multiplying the common stock price at fiscal year-end (item 199) by common shares outstanding (item 25). $B_{i j t}$ is the book value of equity, constructed as stockholders' equity (Compustat item 216) plus balance sheet deferred taxes and investment tax credit (Compustat item 35) minus the book value of preferred stock (Compustat item 56). NI is net income (Compustat Item 172). Since we estimate the regression in logs, we set negative values of net income to zero and include an indicator function for negative values of net income. $L E V_{i j t}$ is the leverage ratio computed as the ratio of total long-term debt (Compustat item 9) to total assets (item 6). In order to reduce the impact of outliers, all variables are winsorized at the $1 \%$ level. [Compustat]

- Industry relative valuation: average total relative valuation of all firms in the three-digit SIC industry, excluding firm $i$.

- Firm variables:

- ROA is defined as operating income after depreciation (item 178) scaled by year-end total assets (item 6). [Compustat]

- Firm size is defined as log of the book value of assets (item 6), deflated by CPI in 1990. [Compustat]

- Industry concentration is the Herfindahl-Hirschman Index (HHI) of the industry, defined as the sum of the squares of the individual company market shares for all the companies in the three-digit SIC industry. [Compustat]

- Investment is capital expenditures (item 128) over assets at the beginning of the fiscal year (item 6). [Compustat]

- Number of acquisitions is the number of all transactions in which a sample firm acted as an acquirer in a given year. [SDC]

- Acquisition probability is a dummy variable that takes the value of one if a firm makes an acquisition bid in a given year and zero otherwise. [SDC]

- R\&D is research and development expenditures (item 46) over sales (item 12). [Compustat]

- Labor productivity is the log of sales (item 12) in 1996 dollars scaled by number of employees (item 29). [Compustat]

- Cost of goods sold is the ratio of cost of goods sold (item 41) to sales (item 12). [Compustat]

- Wages is the log of wages (item 42) in 1996 dollars scaled by number of employees (item 29). [Compustat]

- Sales growth is log of sales (item 12) in year $t$, scaled by sales in year $t-2$. [Compustat] 
- Tobin's Q is the market value of assets divided by the book value of assets (item 6), where the market value of assets equals the book value of assets plus the market value of common equity less the sum of the book value of common equity (item 60) and balance sheet deferred taxes (item 74). [Compustat]

- Cashflow is the sum of earnings before extraordinary items (item 18) and depreciation (item 14) over assets at the beginning of the fiscal year (item 6). [Compustat] 